\title{
The Aerolysin-Like Toxin Family of Cytolytic, Pore-Forming Toxins
}

\author{
Oliver Knapp ${ }^{1}$, Bradley Stiles ${ }^{2,3}$ and Michel R. Popoff*,
}

\author{
${ }^{1}$ Bactéries anaérobies et Toxines, Institut Pasteur, 61-62 rue du Dr Roux, F-75724 Paris cedex 15, France; ${ }^{2}$ Wilson \\ College, Chambersburg, Pennsylvania, USA; ${ }^{3}$ US Army Medical Research Institute of Infectious Diseases, Fort Detrick, \\ Maryland, USA
}

\begin{abstract}
Pore-forming toxins (PFTs) represent the largest known group of bacterial protein toxins to date. Membrane insertion and subsequent pore-formation occurs after initial binding to cell-surface receptor and oligomerization. Aerolysin, a toxin produced by the Gram-negative bacterium Aeromonas hydrophila and related species, belongs to the PFT group and shares a common mechanism of action involving $\beta$-barrel structures resulting from the assembly of $\beta$ hairpins from individual toxin monomers into a heptamer. Aerolysin is also the name given to structurally and mechanistically related toxins called the aerolysin-like toxin family. A universal characteristic of this toxin family involves the diverse life forms that synthesize these proteins throughout Nature. Examples include: 1) epsilon-toxin and septicum-alpha-toxin produced by anaerobic, Gram-positive Clostridium species; 2) enterolobin by the Brazilian tree Enterolobium contortisiliquum; 3) a mushroom toxin Laetiporus sulphureus lectin (LSL); 4) mosquitocidal toxins (Mtxs) from the Gram-positive bacteria Bacillus sphaericus and parasporine-2 from Bacillus thuringiensis; and 6) hydralysins from the tiny aquatic animal Chlorohydra viridis. The following review provides an overview of the different members within the aerolysin-like toxin family.
\end{abstract}

keywords: Pore-forming toxins, aerolysin, septicum-alpha-toxin, enterolobin, epsilon-toxin, Laetiporus sulphureus lectin.

\section{INTRODUCTION}

Many pathogens produce pore-forming toxins (PFTs), which represent more than one third of all bacterial toxins. Bacteria such as Staphylococcus secrete PFTs to alter host cell membranes and trigger nutrient release to stimulate bacterial growth. In addition, cytotoxicity mediated by PFTs counteracts the host defences based on phagocytosis and other immune responses. Indeed, the killing of cells like leukocytes or macrophages facilitates tissue invasion by PFT-producing bacteria [1]. Disruption of cell barriers by PFT-producing bacteria also facilitates their diffusion throughout the host organism. Production of PFTs is common in Gram-negative and Gram-positive bacteria, as well as in higher plants, fungi, and even animals. Among "higher" organisms, PFTs may serve as a defence system for some plants to avoid attacking herbivores or parasites as well as assist certain animals in hunting or digestion.

Members of the aerolysin-like toxin family are synthesised by a very diverse group of organisms composed of: 1) Gram-negative bacteria, such as Aeromonas hydrophila and related Aeromonas species; 2) epsilon- and alpha-toxin respectively from the anaerobic, Gram-positive Clostridium perfringens and Clostridium septicum; 3) enterolobin from Enterolobium contortisiliquum, a Brazilian tree; 4) insecticidal toxins, Mtx and parasporin-2, from Bacillus sphaericus and Bacillus thuringiensis, respectively;

*Address correspondence to this author at the Bactéries anaerobies et Toxines, Institut Pasteur, 28 rue du Dr Roux, F-75724 Paris cedex 15, France; Tel: +33 145688307; Fax: +33 140613123;

E-mail: mpopoff@pasteur.fr
5) Laetiporus sulphureus lectin (LSL) from the mushroom $L$. sulphureus; and 6) hydralysins from aquatic animals in the phylum Cnidaria. Despite the fact that these PFT producers originate from diverse kingdoms represented by plants, fungi and bacteria, all of the PFTs share remarkable sequence identity with aerolysin. It is striking that high sequence homology occurs between aerolysin, septicum-alpha-toxin (72\% similarity [2]), and enterolobin (45\% identity and 59\% similarity, respectively [3, 4]) (Fig. 1A). Despite lower sequence homology of aerolysin with epsilon-toxin (identity $13.9 \%$ [5]), LSL lectin (similarity <20\% [6]), and parasporin-2 (identity $25.7 \%$ [7]) (Fig. 1B), these proteins are members of the same toxin family because of structural similarities between their domains. In addition to structure, another common feature of all these toxins is their mode of action. They all act as cytolysins via pore-formation.

PFTs use two general mechanisms to form pores in cell membranes, either through insertion of amphipathic $\alpha$ helices or B-hairpins organized into a B-barrel [1]. Thus, PFTs are respectively divided into two main groups called $\alpha$ PFT and $\beta$-PFT. Members of the aerolysin-like toxin family use amphipathic $\beta$-hairpins and are therefore rich in $\beta$-sheets. Although B-PFTs share a common mode of pore formation, several types can be distinguished according to their receptor, number of monomers forming oligomers, pore size, and functionality. Like other B-PFTs, aerolysin-like toxins bind to a cell-surface receptor, oligomerize, and generate $B$ hairpins from 6 to 7 individual monomers to form the pore (Table 1). This is opposed to cholesterol-dependent cytolysins (CDCs) which use 40-50 monomers [8] that form a B-barrel structure, insert into the lipid bilayer, and subsequently generate a channel. Furthermore, aerolysin-like toxins form, in comparison to CDCs, small transmembrane 
A

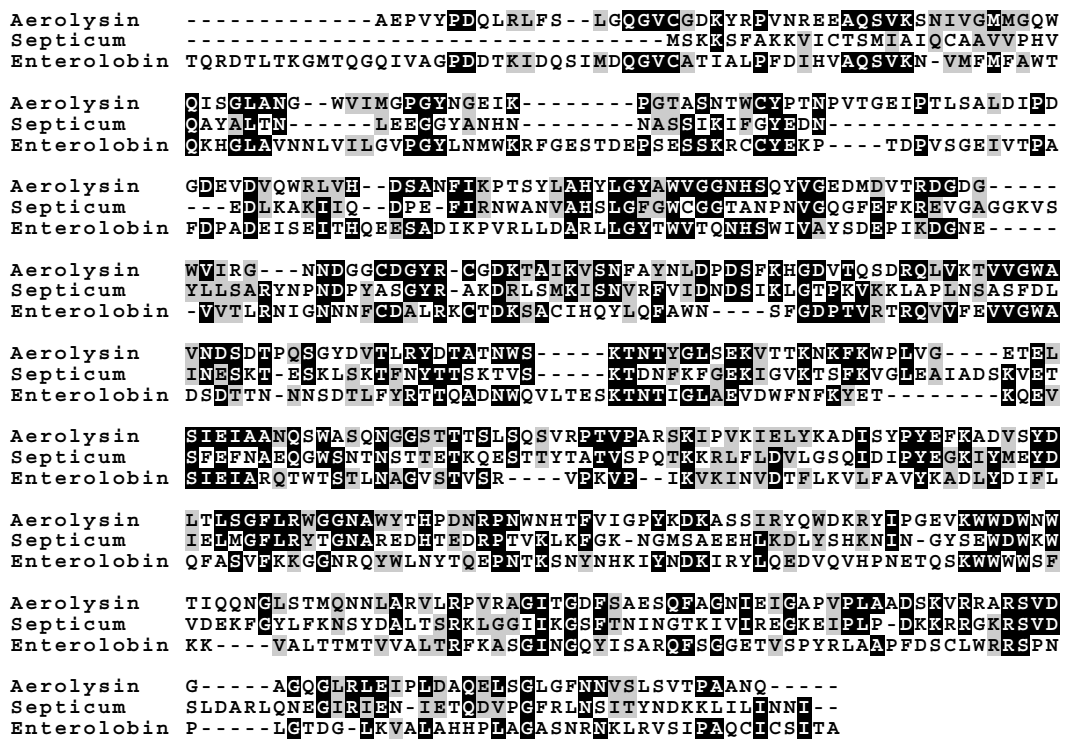

B

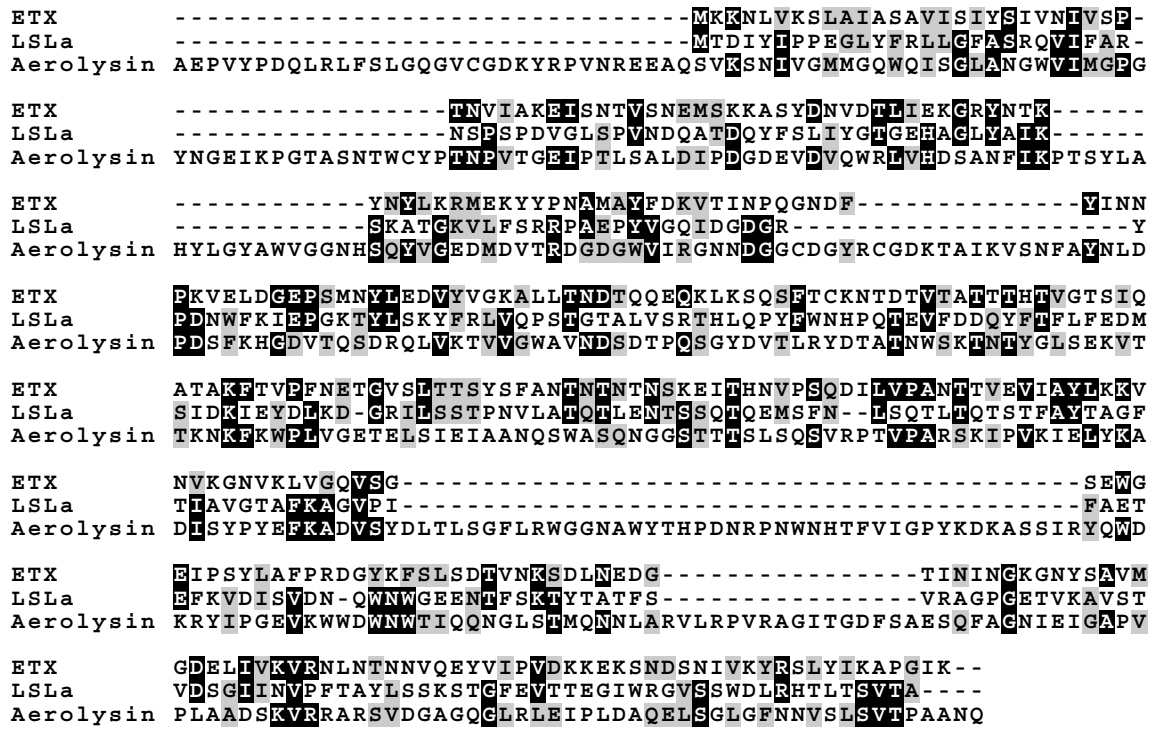

Fig. (1). Sequence alignment of aerolysin-like toxin family members.

A) Alignment of aerolysin with septicum-alpha-toxin septicum and enterolobin, sharing both high sequence identity and similarity (septicumalpha-toxin 72\% similarity [2]; and enterolobin, 59\% similarity / 45\% identity ). Numbering refers to the enterolobin sequence.

B) Alignment of aerolysin with epsilon-toxin ETX and LSLa. Despite lower sequence homology (epsilon-toxin 13.9\% identity, [5] and LSL similarity below $<20 \%,[6]$ ), structural similarities can be observed. Numbering refers to the aerolysin sequence. Strictly conserved regions are shaded in black, and highly conserved regions are light grey.

channels that result from clustering of receptor-bound toxin molecules and oligomerization, followed by insertion into the cell membrane and pore formation. Lipid or protein receptors localized into distinct microdomains facilitate such mobility on cell membranes [1].

Because of the diverse ancestry of PFT-producing organisms, the aerolysin-like toxin family is one of the most phylogenetically-diverse families of PFTs [9]. Resolution of structures that include identification of functional domains within aerolysin, epsilon-toxin, and related toxins [5, 10, 11] allows deeper insight into the structures and mechanisms employed by this toxin family. We now present the most recent data available regarding the aerolysin-like toxin family that includes structures and mechanisms of action.

\section{STRUCTURAL BASIS OF ACTIVITY AND MECHANISM OF ACTION FOR AEROLYSIN, THE PIONEER MEMBER OF THE AEROLYSIN-LIKE TOXIN FAMILY}

Aerolysin is the best-studied molecule of the PFT family. It was the first member associated with cytotoxicity; therefore, aerolysin is commonly used to explain the general mode of action for this toxin family. Aerolysin was discovered and partially purified from the ubiquitous, Gram- 
Table 1. Main Characteristics of Aerolysin-like Toxin Family Members

\begin{tabular}{|c|c|c|c|c|c|c|c|c|}
\hline & $\begin{array}{c}\text { Aerolysin } \\
\text { (Aeromonas } \\
\text { species) }\end{array}$ & $\begin{array}{l}\text { Septicum- } \\
\alpha \text {-Toxin } \\
\text { (Clostridium } \\
\text { Septicum) }\end{array}$ & $\begin{array}{c}\text { Enterolobin } \\
\text { (Enterolobium } \\
\text { Contortisiliquum) }\end{array}$ & $\begin{array}{l}\text { Epsilon-Toxin } \\
\text { Type B and D } \\
\text { (Clostridium } \\
\text { Perfringens) }\end{array}$ & $\begin{array}{c}\text { LSL } \\
\text { (Laetiporus } \\
\text { Sulphureus) }\end{array}$ & \begin{tabular}{|c|} 
MTXs \\
(Mtx2/Mtx \\
3) Bacillus \\
Sphaericus
\end{tabular} & $\begin{array}{c}\text { Hydralysins } \\
\text { (Chlorohydra } \\
\text { Viridis) }\end{array}$ & $\begin{array}{c}\text { Parasporin-2 } \\
\text { Bacillus } \\
\text { Thuringiensis }\end{array}$ \\
\hline $\begin{array}{l}\text { Size in kDA: } \\
\text { (monomer } \\
\text { unprocessed) }\end{array}$ & 52 & 47.5 & 55 & 32.5 & 35 & $31.8 / 35.8$ & 27 & 37 \\
\hline Propeptide: & $\begin{array}{l}\text { yes, N- } \\
\text { terminal }\end{array}$ & $\begin{array}{l}\text { yes, C- } \\
\text { terminal }\end{array}$ & unknown & $\begin{array}{l}\text { yes, } \mathrm{N} \text { - and } \mathrm{C}- \\
\text { terminal }\end{array}$ & unknown & possibly & unknown & $\begin{array}{l}\text { Yes, } \mathrm{N} \text { - and } \\
\text { C-terminal }\end{array}$ \\
\hline Pore formation: & yes & yes & possibly & yes & possibly & possibly & yes & possibly \\
\hline $\begin{array}{c}\text { Channel } \\
\text { conductance G } \\
{[\mathrm{pS}]:}\end{array}$ & & & & & & & & \\
\hline $0.1 \mathrm{M} \mathrm{KCl}$ & 72 & 175 & n.m & 60 & n.m & n.m & n.m & n.m \\
\hline $0.3 \mathrm{M} "$ & 220 & 450 & n.m & 160 & n.m & n.m & n.m & n.m \\
\hline $1 \mathrm{M}$ & 650 & 1250 & n.m & 550 & n.m & n.m & n.m & n.m \\
\hline $3 \mathrm{M}$ & 1700 & 3750 & n.m & 1700 & n.m & n.m & n.m & n.m \\
\hline Receptor & $\begin{array}{c}\text { GPI- } \\
\text { anchored } \\
\text { proteins }\end{array}$ & $\begin{array}{c}\text { GPI- } \\
\text { anchored } \\
\text { proteins, } \\
\text { including } \\
\text { human } \\
\text { folate } \\
\text { receptor } \\
\text { (hFR), Thy- } \\
1 \text { (CD90), } \\
\text { SAG family }\end{array}$ & unknown & $\begin{array}{l}\text { membrane } \\
\text { protein, not GPI- } \\
\text { anchored }\end{array}$ & $\begin{array}{c}\text { unknown, } \\
\text { contains N- } \\
\text { acetyllactosami } \\
\text { ne } \\
\text { glycoconjugate } \\
\text { s }\end{array}$ & unknown & unknown & unknown \\
\hline Target cells & $\begin{array}{l}\text { GPI- } \\
\text { anchored } \\
\text { protein } \\
\text { expressing } \\
\text { cells }\end{array}$ & $\begin{array}{c}\text { GPI- } \\
\text { anchored } \\
\text { protein } \\
\text { expressing } \\
\text { cells }\end{array}$ & $\begin{array}{l}\text { arthropod and } \\
\text { mammalian cells }\end{array}$ & $\begin{array}{c}\text { only a few cell } \\
\text { lines including } \\
\text { kidney cells } \\
\text { (MDCK, } \\
\text { mpkCCD } \\
\text { human renal } \\
\text { leiomyoblastoma, } \\
\text { and G-402 cells) } \\
\text { and glutamatergic } \\
\text { neurons }\end{array}$ & unknown & $\begin{array}{c}\text { mainly } \\
\text { insect cells, } \\
\text { larvae of the } \\
\text { genus } \\
\text { Culex, } \\
\text { Aedes, and } \\
\text { Anopheles }\end{array}$ & $\begin{array}{l}\text { arthropod and } \\
\text { eukaryotic } \\
\text { cells }\end{array}$ & $\begin{array}{c}\text { Liver and } \\
\text { colon cancer } \\
\text { cells and cell } \\
\text { lines (HepG2, } \\
\text { CACO-2) also } \\
\text { human } \\
\text { leukemia T- } \\
\text { cell lines } \\
\text { (Molt-4, } \\
\text { Jurkat, H1-60) }\end{array}$ \\
\hline
\end{tabular}


Table 1. Contd....

\begin{tabular}{|c|c|c|c|c|c|c|c|c|}
\hline & $\begin{array}{c}\text { Aerolysin } \\
\text { (Aeromonas } \\
\text { species) }\end{array}$ & $\begin{array}{c}\text { Septicum- } \\
\alpha \text {-Toxin } \\
\text { (Clostridium } \\
\text { Septicum) }\end{array}$ & $\begin{array}{c}\text { Enterolobin } \\
\text { (Enterolobium } \\
\text { Contortisiliquum) }\end{array}$ & $\begin{array}{c}\text { Epsilon-Toxin } \\
\text { Type B and D } \\
\text { (Clostridium } \\
\text { Perfringens) }\end{array}$ & $\begin{array}{c}\text { LSL } \\
\text { (Laetiporus } \\
\text { Sulphureus) }\end{array}$ & $\begin{array}{c}\text { MTXs } \\
\text { (Mtx2/Mtx3 } \\
\text { ) Bacillus } \\
\text { Sphaericus }\end{array}$ & $\begin{array}{c}\text { Hydralysins } \\
\text { (Chlorohydra } \\
\text { Viridis) }\end{array}$ & $\begin{array}{c}\text { Parasporin-2 } \\
\text { Bacillus } \\
\text { Thuringiensis }\end{array}$ \\
\hline Hemolysis: & yes & unknown & yes & mainly & yes & unknown & yes & no \\
\hline Apoptosis/Necrosis & apoptosis & necrosis & unknown & apoptosis/necrosis & unknown & unknown & unknown & unknown \\
\hline
\end{tabular}

negative fresh water bacterium A. hydrophila in 1975 by Bernheimer et al. [12]. The same toxin was later found to be produced by other species [13] (Table 1). Members of Aeromonas can be pathogenic to a broad spectrum of different hosts including fish, amphibians, reptiles, and mammals. Aerolysin from the different Aeromonas species share a high level of sequence identity [14-18]. In humans, aerolysin is mainly associated with gastrointestinal diseases, but the toxin has also been associated with wound infections, septicemia, and meningitis especially among immunocompromised individuals $[13,19,20]$. Pathogenicity in humans is also a potential problem for the food industry. Among poultry, fish, and shrimp, more than $50 \%$ of the samples for commercially-available raw food and between 20-30\% of processed, ready-to-eat food are contaminated with haemolytic, multiple-antibiotic resistant $A$. hydrophila [21].

Among the different virulence factors produced by Aeromonas species, aerolysin is considered the most important. Immunization against aerolysin leads to protection against the bacterium and toxin. Toxigenic strains of A. hydrophila are lethal to mice, whereas toxin-deficient strains are not pathogenic [22, 23]. Intoxication of host cells by aerolysin occurs through a multi-step process involving each of the toxin's functional domains.

\section{BIOCHEMISTRY AND MODE OF ACTION}

\section{A) Secretion}

Aerolysin is produced as a $52 \mathrm{kDa}$, biologically-inactive protoxin called proaerolysin (Table 1). The molecule enters extracellular medium from the bacterium through a type II secretion system (Fig. 2, step 1) [24, 25]. Translocation across the inner bacterial membrane is mediated by a signal peptide subsequently removed upon transport [24, 25]. At least twelve proteins are involved in the next transport step across the outer bacterial membrane [26, 27]. While proaerolysin is transported across the inner membrane in its unfolded state, the molecule becomes fully folded when transported across the outer membrane [28]. Hardie et al. (1995) [29] could show that replacement of Met-41 with Cys results in dimers within the periplasmic space, which are then transported across the outer membrane [29]. Important parts of the secretion system are composed of the inner membrane proteins ExeA and ExeB [30], as well as an outer membrane protein ExeD [31]. Signals for secretion are located within the large lobe (domains 2-4) (see below for structure). The small lobe alone has reduced secretion versus the wild type structure [32]. Proteolytically-activated monomers oligomerize spontaneously at high concentrations [9, 33] (Fig. 2, step 2). It was shown for both proaerolysin and the mature form that they remain as dimers in solution. This was demonstrated through ultracentrifugation, chemical crosslinking, and a final electrophoresis step [34]. Fivaz et al. [33] claimed that proaerolysin exists only as a dimer at concentrations $>100 \mu \mathrm{g} / \mathrm{ml}$; whereas, it is monomeric at concentrations $<100 \mu \mathrm{g} / \mathrm{ml}$ which also favours receptor binding. In contrast, Barry et al. [35] claimed that the proaerolysin dimer is also stable at concentrations $<100$ $\mu \mathrm{g} / \mathrm{ml}$, and in fact down to $<5 \mu \mathrm{g} / \mathrm{ml}$ which also binds receptor.

\section{B) 3-D Structure}

The crystal structure of proaerolysin dimer has been solved (Fig. 3A). The monomers are L-shaped molecules with a small $\mathrm{N}$-terminal lobe (domain 1 ) rich in $\beta$-structure with a low number of $\alpha$-helices [9, 36]. It can not be excluded that monomer structure differs from dimer. Nevertheless, the monomer has a bilobal structure divided into the little lobe, consisting of domain 1 (residues 1 to 82) [37], and a large, elongated lobe split into three additional domains 2 to 4 (residues 83 to 470) [36] with characteristic long $\beta$-strands. Domain 1 of aerolysin shares structural homology to S2 and S3 subunits of pertussis toxin, which are involved in receptor binding [38]. Domains 1 (residues 1 to 82) [37] and 2 (residues 83 to 178 and 311 to 398) [37] are involved in receptor binding and dimerization of aerolysin. Important residues for binding are Trp-45, Ile-47, Met-57, Tyr-61, and Lys-66 of domain 1, as well as Tyr-162, Trp324, and His-332 of domain 2 [38-40]. Disulfide bridges between Cys-19 and Cys-75 in domain 1, and Cys-159 with Cys-164 of domain 2 increase protein stability and protect loop 154-167 from degradation by proteases [41]. Domain 2, together with domain 3 (residues 179 to 194,224 to 274,299 to 310 , and 399 to 409) [37], is also involved in oligomerization and maintenance of the oligomers [41]. Trp at positions 371 and 373 seems to have a direct effect on oligomerization, since an exchange with Lys accelerates this process [37]. Van der Goot et al [34] suggest that these residues contribute to dimer stability or establishing contact between subunits in the oligomers [41]. Domain 3 shows sequence similarities to other pore-forming toxins like Staphylococcus aureus alpha-toxin [42] or channel-forming components of binary toxins such as the protective antigen (PA) from Bacillus anthracis [37, 43]. The channel-forming region within this domain is defined by disulfide trapping and cysteine scanning mutagenesis coupled to thiol-specific labeling on lipid bilayers. The transmembrane region 
consists of $\sim 20$ amino acids, forming two amphipathic $\beta$ sheets connected by a hydrophobic region of 5 residues that altogether generate a $\beta$-hairpin [11]. The hydrophobic turn of the $\beta$-hairpin seemingly drives membrane insertion and folds back after membrane crossing in a rivet-like fashion. After heptamerization, these $\beta$-hairpins form during membrane insertion and $\beta$-barrel formation, comparable to outer membrane porins of Gram-negative bacteria [11, 44]. Domain 4 is located on the major lobe's tip (residues 195 to 223, 275 to 298, and 410 to 470) [37] and contains the Cterminal peptide released upon proteolysis. Proteolytic cleavage occurs between residues 422 to 440 of a long flexible loop by a broad spectrum of proteases (see above). As a consequence of activation, there might be reorganization of the different domains and/or helical pitch of the large loop that ultimately favors oligomer formation. Despite the oligomeric, pore-forming complex being very stable and relatively insensitive to changes in ionic strength and $\mathrm{pH}$ [37], crystals of this complex have not been obtained to date. It has only been possible to analyze two-dimensional crystals associated with Escherichia coli phospholipids [45] and electron microscopy [37]. The observed oligomers show, like the $S$. aureus alpha-toxin, a mushroom-like structure [37, 45]. According to Rossjohn et al. [37], domains 1 and 2 form the mushroom-shaped head while domains 3 and 4 generate the stalk. Parker et al. assumed that domain 3 is involved in forming the channel mouth, whereas domain 4 crosses the membrane bilayer to line the pore [10]. This model was proven wrong by Rossjohn et al. as they show through site-directed mutagenisis that the trans-membrane loop is located in domain 3 [37]. However, the main assumption is still valid that rapid exposure of hydrophobic residues from the transmembrane loop to the host cell membrane may be triggered through proteolytic activation, thus resulting in conformational changes [10, 37]. Several parameters that include toxin and receptor concentrations are seemingly required for the final event of pore formation [37]. Proteolytic activation induces a distinct change in secondary structure that coincides with reorganization of random structures, thereby increasing the $\beta$-sheet content. Release of the propeptide is essential for conformational and structural changes not restricted to the cleavage site, but which propagate throughout the molecule. Subsequent processes like oligomerization and membrane insertion after propeptide release have no influence on the secondary structure, but formation of heptamers changes the tertiary interactions [46]. It could be shown that propeptide release from Aeromonas sobria hemolysin converts the prohemolysin into an active form with the carboxy terminal region contributing to proteolytic stability. However, despite the fact that the N-terminus of $A$. sobria hemolysin is homologous to aerolysin, the C-terminal region shares no homology [47]. A similar effect of the aerolysin propeptide can therefore not be excluded. Conversion of a hydrophobic channel-forming heptamer into a water-soluble protein complex can easily be achieved by mutating Tyr-221 to Gly. This mutation inhibits hemolytic activity but has no influence upon oligomerization or receptor binding. Overall structure of the mutated complex shows no remarkable difference versus wild type; however, the former molecule does differ in that it is completely hydrophilic [48]. Domains 2-4 are rich in $\beta$-sheets and related to domains 1-3 of the single-lobed epsilon-toxin (Fig. 3A, B), as well as the model of septicum-alpha-toxin. Interestingly, the structure of epsilon-toxin is highly related to aerolysin, despite a low $(14 \%)$ amino acid sequence identity $[5,10]$. Some differences in the receptor binding domain 2 suggest that epsilon-toxin binds to a different receptor than aerolysin, which could also be the reason for epsilon-toxin's $>100$-fold higher toxicity $[5,49,50]$. Structural comparisons between LSL, epsilon-toxin, parasporin-2 (see Fig. 3A and B, C, D), and aerolysin (see Fig. 3A) reveal similarities between domains 2 and 3 of LSL and epsilon-toxin with domains 3 and 4 of aerolysin. The septicum-alpha-toxin shares a relatively high sequence homology with aerolysin domains 2-4 (72\% similarity, 27\% identity) [2, 15]. Domain 4 occurs in channel formation and contains the $\mathrm{C}$-terminal peptide released upon proteolytic cleavage. However, one clear difference between the septicum-alpha toxin versus epsilontoxin and aerolysin is an additional domain (domain I) in aerolysin, which seemingly binds to receptor.

In general, all members of the aerolysin-like toxin family are rich inb-strands. This assumption was confirmed by the crystal structure of water-soluble forms of aerolysin, epsilontoxin, LSL, and most recently parasporin-2 [5, 6, 7, 10] (Fig. 3D), as well as through CD spectroscopy of epsilontoxin and LSL [51, 52]. All remaining members of the aerolysin-like toxin family are devoid of a sequence corresponding to domain 1 of aerolysin. Thus, these proteins consist of a single-lobed, elongated structure containing three domains homologous to domains 2-4 of aerolysin [2, 3, $5,6,7,10]$. Domains 1 and 3 are generally involved in oligomerization, while receptor binding is restricted to domain 1 [53]. Residues within domain 1 regulate insertion of the transmembrane b-hairpin located within domain 2 [53].

\section{C) Receptor Binding}

Aerolysin monomers, but not oligomers, bind to specific cell-surface receptors [33] (Fig. 2, step 3) identified as glycosyl-phosphatidyl-inositol (GPI)-anchored proteins (Table 1). The GPI anchor attaches many cell-surface proteins into the cell membrane, especially through lipid rafts. Because of the ubiquitous distribution of GPI-anchored proteins and their multiple functions as enzymes, antigens, adhesion molecules, or receptors for various ligands that include bacterial toxins, aerolysin interacts with a wide variety of cell types [32, 54-56]. Aerolysin recognizes the GPI anchor as well as associated glycosylated proteins. Although aerolysin possesses two different binding regions within the toxin, each recognizing different parts of the receptor, each region is unable to mediate aerolysin binding without the other. Biacore measurements reveal binding of aerolysin to the GPI-anchored proteins Thy-1, variant surface glycoprotein (VSG), and contactin. Relative to whole toxin, binding of the small lobe (domain 1) to Thy-1 is 5000fold weaker and that of the large lobe (domains 2-4) >50fold weaker [39]. The posttranslational modification of $\mathrm{N}$ glycan structures (minimal structure containing $\mathrm{N}$-acetylglucosamine, mannose and asparagine) on glycosylated proteins is recognized by domain 1 of aerolysin (see below), whereas domain 2 binds to the GPI anchor. Many GPIanchored proteins, containing the proper N-glycan posttranslational modification, can be used by aerolysin as a 


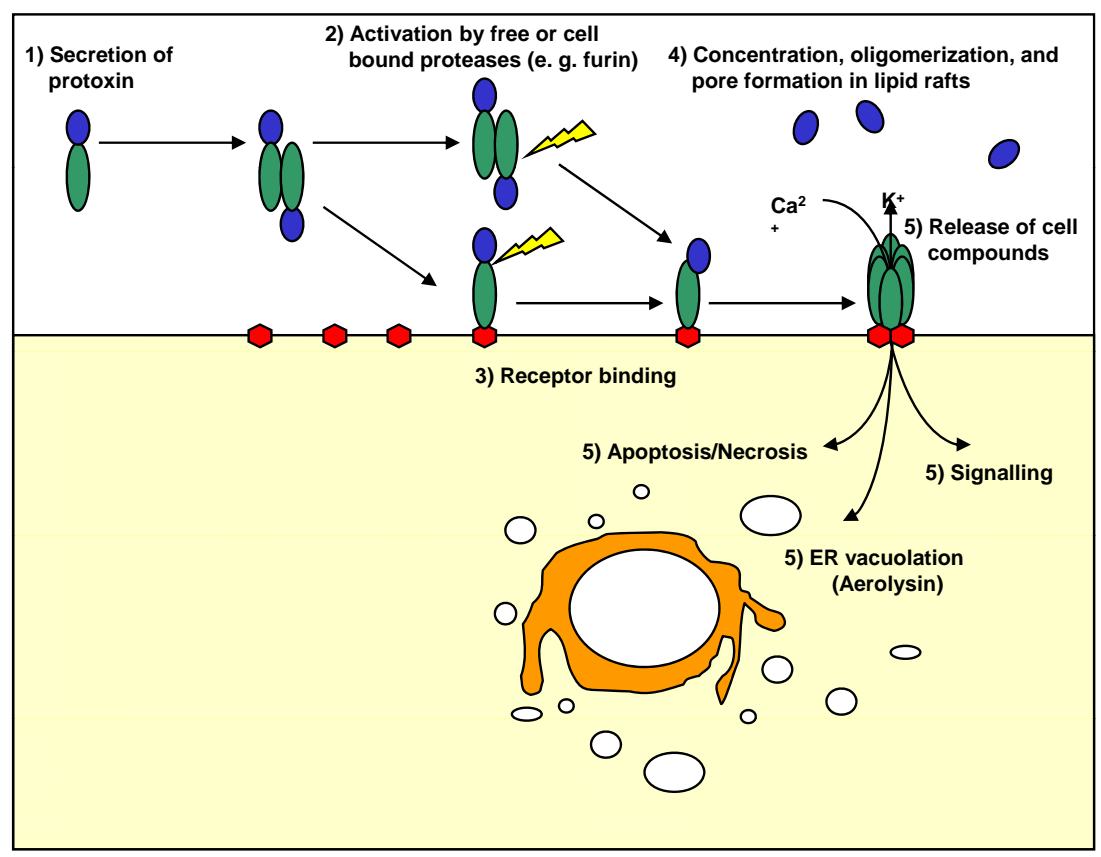

Fig. (2). Schematic model of aerolysin-like toxin uptake. (1) Secretion of toxin (aerolysin) monomer with head-to-tail dimers formed in solution (2/3). Proteolytic cleavage results in activated monomers and propeptide release. Although proteolysis can occur in solution, activation mainly occurs after receptor binding on the cell surface (4). Oligomerization and pore formation occurs in lipid rafts due to concentrating effects (5). Pore formation results in several cellular responses that include vacuolation of the ER by aerolysin.
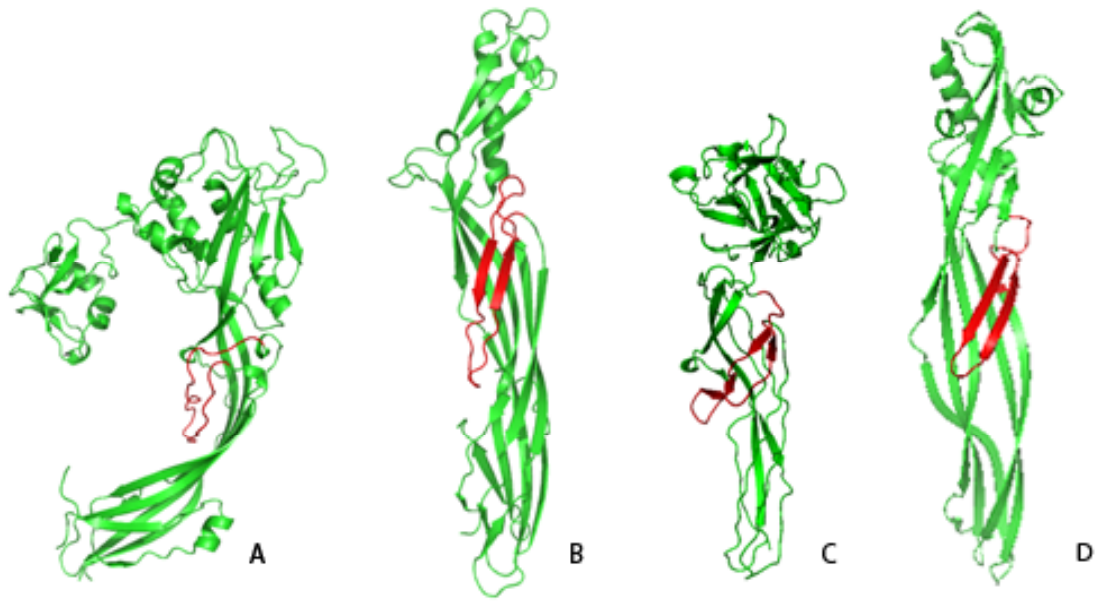

Fig. (3). Crystal structure of aerolysin-like toxin family members.

Crystal structures of (A) aerolysin from A. hydrophila [10], (B) epsilon-toxin from C. perfringens [5], (C) LSL from L. sulphureus [6], and (D) Parasporin from Bacillus thuringiensis [7]. The pore forming $\beta$-hairpins are highlighted in red.

receptor. Receptors include Thy-1 [55], contactin [32], CD14, carboxypeptidase M or NCAM (neural cell-adhesion molecule) [57], and even the variant surface glycoprotein (VSG) of Trypanosoma brucei [39]. Aerolysin binding to GPI-anchored proteins can be used to detect and concentrate eukaryotes of the genus Leishmania or Trypanosoma. Trypanosomes are remarkably insensitive to aerolysin, and the reason might be a dense packing of GPI-anchored proteins [58] that hinder access to the plasma membrane. After a selective lysis of erythrocytes and leukocytes by aerolysin, which does not affect African trypanosomes, the latter can be easily detected [59]. Zheng et al. [60] showed that septicum-alpha-toxin kills Leishmania major parasites, with a $50 \%$ lethal concentration of $0.77 \mathrm{nM}$. However, a few
GPI-anchored proteins like CD59 [61] and gp63 from Leishmania prevent aerolysin binding, but the binding ability of gp63 can be restored when expressed in mammalian cell lines [32]. An explanation could be a different posttranslational modification pattern in mammalian cell lines. Surface plasmon resonance experiments by MacKenzie et al. [39] identified crucial residues within domains 1 (Trp34, Tyr-62, Lys-66) and 2 (Lys-171, Trp-324) that affect receptor binding. Indeed, cell lines with a reduced ability to produce the GPI anchor, or those treated with inositolspecific phospholipase $\mathrm{C}$, are less sensitive to aerolysin $[55,62]$.

\section{D) Proteolytic Activation}


Activation of secreted aerolysin precursor consists of proteolytic removal of 41 to $43 \mathrm{C}$-terminal residues within a flexible loop (domain 4) while the toxin is in solution or bound to receptor (Fig. 2, step 2). Additionally, no significant difference in binding between proaerolysin and mature aerolysin could be observed [39]. Many eukaryotic proteases found in the digestive tract, such as trypsin (cleavage site on proaerolysin Lys-427), $\alpha$-chymotrypsin (Arg-429), and furin (Arg-432) in solution or on the cell surface [36, 63], as well as proteases secreted by Aeromonas [64], activate the hydrophilic protoxin monomers. Activation is accompanied by a conformational change essential for aerolysin activity, as it enables a water-soluble protein to expose hydrophobic residues necessary for insertion into host cell membranes and forming persistent membrane channels. Such residues can be found normally in the interior of water-soluble proteins; hence, a conformational change is expected to accompany channel formation. The ability to exist as water-soluble proteins and form pores in lipid membranes requires two, alternatively-stable conformations. It seems that peptide removal favours oligomerization by reducing the energy barrier leading to an extremely stable aerolysin heptamer [24]. Differences in conformation throughout the entire molecule have been observed between aerolysin and proaerolysin using fluorescence [65] and infrared spectroscopy [46]. However, these changes promoting oligomerization have not been more closely evaluated [24]. Comparative studies of A. sobria hemolysin with aerolysin of $A$. hydrophila reveal that the carboxy terminal region of proaerolysin may also contribute to toxin stability towards proteolytic degradation [47].

\section{E) Oligomerization and Pore-Formation}

Binding to GPI-anchored proteins, which are mainly localized in lipid rafts, concentrates toxin monomers into these restricted cell-surface microdomains that favor monomer clustering and subsequent oligomerization (Fig. 2, step 4) [1]. Proteolytic cleavage occurs after receptor binding and approximately 40 residues are removed from the aerolysin C-terminus. Both events, receptor binding and proteolytic activation, reflect important conditions that trigger oligomerization. Even at low picomolar concentrations, oligomerization takes place mainly on the surface of host cell membranes [66] but aerolysin can also oligomerize in solution to form very stable heptamers (Table 1). However, oligomerization is much more efficient on cells due to the concentrating effect of receptor binding and accumulation into lipid rafts [66]. During steady state, only about $30 \%$ of GPI-anchored proteins are associated with lipid rafts. Thus the majority of GPI-anchored proteins are not localized within lipid rafts but all have the capacity to become transiently associated with these membrane microdomains. Activated monomers assemble into heptamers through domains 3 and 4 interactions, as well as form channels through insertion into lipid bilayers as observed indirectly by electron microscopy since only the mushroom cap and not the transmembrane region are visible [45]. Several mutations affecting oligomerization have been identified. His-132, for example, requires protonation to facilitate oligomerization and mutation of this residue abolishes pore formation [67-69]. Trp-371 and -373 accelerate the heptamer formation process [34]. Unlike other
PFTs like $S$. aureus alpha-toxin [70, 71], aerolysin apparently does not form a pre-pore complex. Heptamerization is accompanied by exposing hydrophobic areas in domain 3 and insertion into membrane [11]. At this point, there are at least two phases of toxin-mediated cytotoxicity: specific binding upon target cells via the GPI-toxin receptor and membrane insertion. Lipid bilayer studies reveal that electrostatic forces play an important role during the reversible adsorption phase of RTX (Repeats in ToXin)toxins such as E. coli alpha-toxin or adenylate cyclase toxin from Bordetella pertussis [72-74]. Conformational change drives an unfolding of the antiparallel amphipathic loop from each monomer and formation of an amphipathic transmembrane 14-stranded- $\beta$-barrel that inserts into the membrane to form pores [75, 76] (Fig. 2, step 4). A domain 3 (domain 2 for other toxin family members) loop seems to move away from the core $\beta$-sheet and with the loops of other monomers forms a transmembrane channel. Hydrophobic amino acid side chains of each $\beta$-strand interact with the lipid bilayer core, whereas the hydrophilic residues face the channel lumen $[50,62,76,77]$. Once inserted into the membrane, heptamers cannot be removed without using detergents. A similar effect is also expected for members of the aerolysin-like toxins. An aerolysin heptamer is extremely stable, even to boiling in SDS [78], and has a mushroomshaped structure like that of $S$. aureus alpha-toxin [42, 79]. However, the pore structure of aerolysin heptamer is not yet well defined. A loop from domain 3 is involved in B-barrel formation [25]. Heptamers inserted into the membrane form voltage-dependent, anion selective channels with a single channel conductance of about $70 \mathrm{pS}$ in $0.1 \mathrm{M} \mathrm{KCl}$ which corresponds to a pore diameter of at least $7 \AA$ [73] (Table 1). Wilmsen et al. estimated a fairly similar diameter of $9.3 \AA$ [45]. Some unclarity still remains for the pore diameter since it is estimated by Parker et al. and Tisitrin et al. [10, 48] at $17 \AA$, $30 \AA$ by Howard and Buckley [80], and between 19 and $23 \AA$ by Tschödrich-Rotter et al. [81]. These variations might be caused by the use of different techniques. Parker et al. used cryo-negative staining electron microscopy [10], Howard and Buckley measured the release of labeled molecular weight markers [80], while Tschödrich-Rotter et al. used the scanning microphotolysis method [81]. The channel-forming domain of aerolysin could be identified through sequence alignments with other PFTs like $S$. aureus alpha-toxin [42] or channel forming components of binary toxins like PA from Bacillus anthracis [37, 43]. Additionally, the channel-forming domain of aerolysin has been determined through altering channel properties in biophysical experiments by insertion of different mutations (see below; [11]). Therefore, channel formation for not only aerolysin, but also the $S$. aureus alpha-toxin and other $\beta$ barrel pore forming toxins, marks a crucial step in biological activity.

\section{F) Consequence of Pore Formation}

As a consequence of anion-selective transmembrane channels being formed, a cell can readily lose ions, water, and small molecules (i.e. sugars, amino acids, nucleic acids) that do not include proteins [56, 78]. Besides breakdown of the $\mathrm{Na}^{+} / \mathrm{K}^{+}$gradient, an influx of $\mathrm{Ca}^{+2}$ can be observed in cells, which seemingly mediates cell signalling [82] (Fig. 2, step 5). Loss of $\mathrm{K}^{+}$facilitates formation and activation of the 
inflammasome, cytoplasmic multiprotein complexes harbouring Nod-like receptors such as IPAF and NALP3, as well as caspase-1 [56]. Finally, via caspase- 1 the $\mathrm{K}^{+}$efflux mobilizes Sterol Regulatory Element Binding Protein (SREBP)-1 and -2. Both proteins are involved in the biogenesis of membranes and their activation enhances cell survival [57]. Caspase-1 is also responsible for the processing and activation of cytokines IL-1 $\beta$ and IL-18 [83], which is also observed during aerolysin intoxication. Furthermore, it has been shown that IL-8 is produced as a consequence of NF- $\kappa \mathrm{B}$ pathway activation in macrophages with aerolysin [22]. Intoxicated cells stay alive for several hours, depending upon the toxin concentration [32]. Additional effects, besides pore formation, include increasing cell membrane permeability contingent upon the number of pores and finally cell lysis. Formation of intrinsic ion channels and loss of membrane integrity induce a number of signalling pathways resulting in release of secondary messengers (Fig. 2, step 5). In granulocytes, secondary messengers activate $\mathrm{G}$ proteins, leading to production of inositol(1,4,5)-triphosphate (IP3) and release of $\mathrm{Ca}^{2+}$ from the endoplasmic reticulum (ER) through IP3dependent channels [82]. This effect is directly linked to channel formation since inactive channel mutants (Tyr-221 to Gly, Gly-202 to Cys, and Ile-145 to Cys) do not elicit these effects through receptor binding alone [82]. In T cells, aerolysin channel formation results in DNA fragmentation which is a sign of apoptosis [84] (Fig. 2, step 5; Table 1). Aerolysin-induced apoptotic effects have also been shown in murine macrophages [85], and the eliciting factor seems to be $\mathrm{Ca}^{2+}$ influx through the aerolysin channels [84] or a secondary effect linked to toxin-induced TNF $\alpha$ [86]. It is thought that apoptosis is caused through a massive entry of $\mathrm{Ca}^{2+}$. Interestingly, induction of apoptosis could not be observed in all cell types [24]. As an additional effect, vacuolation of the ER can be observed in epithelial cells (Fig. 2, step 5); however, this is seemingly not linked to $\mathrm{Ca}^{2+}$ entry and induction of apoptosis, since $\mathrm{Ca}^{2+}$ ionophores and overexpression of an anti-apoptotic protein (Bcl-2) does not protect against ER vacuolation [56, 64]. Exposure to EGTA prevents ER vacuolation [57]. Aerolysin does not alter morphology of the Golgi complex and endocytic compartments, or induce degradation of DNA [56, 64]. Vacuolation is inhibited by either ATP depletion or depolymerization of the microtubule network. How this effect is elicited by aerolysin remains unclear, even though there is now evidence that toxin enters the cell [24].

Bacillus thuringiensis Cry5B, a cytolytic pore-forming toxin not related to the aerolysin-like family, induces passive uptake of ions leading to host cell swelling. Such actions ultimately result in up regulation of two MAPK pathways, p38 and c-Jun N-terminal kinase (JNK)-like. Activation of the p38 pathway facilitates divalent cation transport [87]. Furthermore, the p38 pathway is involved in membrane resealing after cell intoxication with $S$. aureus alpha-toxin [88]. MAPK pathways provide a significant defence against the toxin, as inhibition of p38 in aerolysin-treated baby hamster kidney cells results in hypersensitivity. It can be assumed that aerolysin influences both MAPK pathways [87]. Finally, it should be considered that as aerolysin is anion selective, transport of negatively charged ions across the cell membrane could also contribute to the observed effects.

\section{Members of the Aerolysin-Like Toxin Family}

\section{Alpha-Toxin from Clostridium septicum (Gram- Positive, Prokaryote)}

The septicum-alpha-toxin is secreted by the highly virulent pathogen $C$. septicum. This anaerobe is a major cause of necrotizing enterocolitis and enterotoxemia in animals. C. septicum is also involved in nontraumatic myonecrosis and gas gangrene of the intestinal wall that includes a necrotizing enterocolitis in humans subsequent to colon malignancy [89-91] (Table 1). The septicum-alphatoxin, a $47.5 \mathrm{kDa}$ protein (Table 1), is the only known virulence factor of C. septicum absolutely required for pathogenesis [92]. Purified toxin is lethal for mice [50], and cytotoxic for CHO cells [93] as well as many other nucleated cell lines [94]. The toxin also causes membrane damage and lysis of tachyzoits from the protozoan parasite, Toxoplasma gondii [95]. The septicum-alpha-toxin gene has been sequenced from 25 clinical isolates, and although the deduced proteins have very few changes they can still be divided into 7 groups (based upon amino acid sequence variations). However, no differences in molecular weight, toxicity, and antigenic cross-reactions have been observed [96].

Septicum-alpha-toxin is hemolytic, dermonecrotic, and lethal with a reported mouse median lethal dose $\left(\mathrm{LD}_{50}\right)$ of 10 $\mu \mathrm{g} / \mathrm{kg}$ [97]. The septicum-alpha-toxin is encoded by the csa gene $[2,75]$ and secreted from the bacterium by a signal peptide evident as an inactive protoxin, probably via the type II secretion pathway [97]. Proteolytic activation occurs by removing a C-terminal peptide of 45 residues $[93,98]$ (Table 1). Various proteases can activate septicum-alpha-toxin, such as trypsin and proteinase $\mathrm{K}$, but furin found on the cell surface seems to be the main activator in vivo.

The crystal structure of septicum-alpha-toxin has not been solved, but based on that of aerolysin and the high degree of similarity ( $72 \%$ similarity at the amino acid level) between domains 2-4 of both toxins, it is possible to generate a molecular model of the water-soluble form [76]. Septicumalpha-toxin does not form a dimer in solution [98] and possesses a higher amino acid sequence identity (27\%) [2] with aerolysin than epsilon-toxin (13.9\%) [5] (Fig 1A). Several residues contributing to oligomerization and receptor binding could be identified through site-directed mutagenesis [53], but one important difference versus aerolysin is formation of a prepore. Furthermore, by using cysteinescanning mutagenesis with multiple spectrofluorimetric models it is possible to identify the channel-forming domain between residues 203-232. Deletion of up to $90 \%$ of the membrane-spanning domain affects pore formation, but has no effect upon other features like activation, cell binding, and oligomerization [76]. A disulfide bond was designed by introducing Cys residues for Ser-220 and Ser-269. Like that for aerolysin [37], reduction of these residues restores alphatoxin activity and demonstrates necessary flexibility of the $\beta$ hairpin.

Precursor for septicum-alpha-toxin monomer binds to GPI-anchored membrane proteins on target cells [62] (Fig. 2, 
step 3). Cells unable to synthesize GPI anchors have reduced, or complete, loss of toxin sensitivity [62]. However, receptors for the septicum-alpha-toxin and aerolysin are different. Multiple cellular receptors of septicum-alpha-toxin include the human folate receptor (hFR), neuronal surface molecule contactin, Thy-1 (CD90) [62], as well as proteins out of the SAG (Sensitive to Apoptosis Gene) family which are on the surface of Toxoplasma gondii [95] (Table 1). Whereas carbohydrates linked to the GPI-anchor may be important for binding of aerolysin and septicum-alpha-toxin, the N-glycan of anchored proteins is seemingly not important for binding of septicum-alpha-toxin [99]. The septicum-alpha-toxin lacks domain 1 found in aerolysin, perhaps explaining the different binding behaviors of these toxins to GPI-anchored proteins. Indeed, a hybrid protein consisting of domain 1 from aerolysin fused to septicumalpha-toxin retains binding capability to receptors so far restricted to aerolysin [40].

Receptor bound septicum-alpha-protoxin requires activation by furin and possibly other cell-surface proteases (Fig. 2, steps 2 and 3). Activation of septicum-alpha-toxin in solution leads to aggregation of monomers into nonfunctional oligomers; however, activation of toxin after receptor binding results in functional oligomers. The propeptide stays associated with the activated toxin monomers by non-covalent interactions and acts as an intramolecular chaperon [98], thereby preventing the toxin from undergoing incorrect folding or oligomerization in solution [98]. Dissociation of the propeptide occurs during oligomerization and stabilization of the septicum-alpha-toxin monomer is then no longer required. The propeptide is located within domain 3 of septicum-alpha-toxin and probably protects an interfacial domain involved in monomer interactions [9]. It has been possible to observe septicum-alpha-toxin channels in vitro with the black lipid bilayer technique. Channels formed in this assay are slightly anion selective with a single-channel conductance of 140$180 \mathrm{pS}$ in $100 \mathrm{mM} \mathrm{KCl}$ [77] (Table 1). Like that for other PFTs, the binding to cell receptor, oligomerization, as well as subsequent channel formation has different kinetics. Pore formation is completely abrogated at $4^{\circ} \mathrm{C}$, whereas binding to cells and oligomerization occurs at $25^{\circ}$ and $37^{\circ} \mathrm{C}$ [98]. Pore diameter formed by septicum-alpha-toxin is estimated between 1.3 and $1.6 \mathrm{~nm}[50,62,76,97]$ (Table 1). Septicumalpha-toxin induces a rapid $\mathrm{K}(+)$ efflux, deregulation of mitochondrial activity, increased ROS levels, and dramatic ATP depletion followed by cell necrosis, characterized by cell permeabilization to propidium iodide without DNA fragmentation and activation of caspase-3 which is oppositional to the apoptosis-inducing aerolysin [100, 101]. An also reported increase in intracellular $\mathrm{Ca}^{2+}$ levels seems to be not the initial effect, since incubation of the cells in $\mathrm{K}^{+}$-enriched medium delayed cell death. These results suggest that the fast loss of intracellular $\mathrm{K}^{+}$represents an early signal of pore-forming toxins-mediated cell necrosis $[100,101] . \mathrm{Ca}^{2+}$ influx seems to be associated with calpain activation and release of cathepsins from lysosomes. Finally, the immunostimulatory histone binding protein HMGB1 was found to be released from the nuclei of alpha-toxin-treated cells [101].
2. Enterolobin from Seeds of Enterolobium contortisiliquum (Eukaryotic Plant - Brazilian Tree)

Enterolobin, a $55 \mathrm{kDa}$ cytolytic, insecticidal protein is produced by seeds of the tropical tree Enterolobium contortisiliquum belonging to the family of Mimosaceae [3, 102, 103] (Table 1). Although this tree grows mainly in coastal areas of Costa Rica and throughout temperate zones of South America, it also resides up to 900 meters above sea level. E. contortisiliquum can grow as high as $40 \mathrm{~m}$ and is well adapted to the dry season. The seeds germinate in high humidity and elevated temperatures, of which the latter includes a heat impulse caused by bush fires. Enterolobin was first purified by Sousa et al. in 1989 [102]. Since enterolobin harbours insecticidal activities against larvae of the brucid Calosobruchus macullatus [102], and causes inflammation upon injection in rats [104], it may serve as a defence against potential herbivores. Three known outbreaks of intoxication have also been caused by $E$. contortisiliquum pods [105] consumed by cattle, leading to anorexia, depression, photosensitization, and abortion. Generally, these animals fully recovered within 30 to 40 days. Calves fed $E$. contortisiliquum seeds had gastrointestinal irritation and liver degeneration [105]. Furthermore, it was shown that mouse erythrocytes were less susceptible to haemolysis by enterolobin than human and rabbit erythrocytes [102] (Table 1).

The primary structure of enterolobin appears to be more related to aerolysin than to the septicum-alpha- or epsilontoxins. Enterolobin displays sequence identity (45\%) and similarity $(59 \%)$ with both the small and large lobes of aerolysin (Fig. 1A). Little is known about the cytolytic mechanism of enterolobin, but it seems to act via oligomerization and pore formation (Fig. 2). Indeed, enterolobin apparently forms stable dimers in solution at concentrations as low as $10 \mu \mathrm{g} / \mathrm{ml}[4,62,102,103]$. In addition, similar residues to proaerolysin Trp-371 and Trp373 responsible for protein dimer maintenance in solution can be found in enterolobin with Trp-386 and Trp-387 [4]. A light-scattering experiment showed that oligomerization of enterolobin was promoted by low $\mathrm{pH}$ and high ionic strength. Several key residues involved in oligomerization of aerolysin (His-107, His-132, and Cys-159) are also conserved in enterolobin (His-127, His-154, and Cys-183) [4]. Additionally, Trp-227 involved in secretion of aerolysin [45] is also aligned with Trp-247 in enterolobin. A different receptor-binding domain of enterolobin, when compared to proaerolysin, is to be supposed since residues responsible for receptor binding of proaerolysin are deleted or substituted in enterolobin [103]. These data suggest that enterolobin recognizes a different receptor. The cleavage site for trypsin or $\alpha$-chymotrypsin in aerolysin corresponds to a nonconserved tripeptide Asp-Ser-Cys (residues 437-439) in enterolobin. Up to now, it is unknown if proteolytic activation of enterolobin further increases haemolytic activity [4].

3. Epsilon-Toxin from Clostridium perfringens (GramPositive, Prokaryote)

Epsilon-toxin is produced by the widespread, sporeforming bacterium $C$. perfringens. In addition to soil, $C$. perfringens can also be found as an intestinal resident in a 
variety of different animal species, including humans. $C$. perfringens strains are classically placed into five types, depending on the production of four major toxins (Alpha, Beta, Epsilon, Iota). Types B and D produce epsilon-toxin [106] (Table 1). The epsilon-toxin represents a main pathogenicity factor [107], belonging just beneath the botulinum and tetanus neurotoxins as the most potent clostridial toxins when tested by mouse lethality assay [108]. Epsilon toxin is responsible for fatal enterotoxaemia in sheep, goats, calves, and other domestic animals [42, 109]. Proliferation of clostridia in the intestine produces large amounts of epsilon-toxin. Absorption of toxin occurs via the intestinal mucosal barrier and then spreads into all organs by the blood stream, preferentially accumulating in the brain and kidneys [110]. Within infected animals, the toxin promotes blood pressure elevation and edema throughout the viscera such as intestines and lungs. The toxin induces extensive kidney damage, known as "pulpy kidney disease", and is characterized post-mortem by tubule cell necrosis and medullary interstitial hemorrhage [42, 111-114]. An epsilontoxin-Green Fluorescence Protein (GFP) fusion injected intravenously into mice binds mainly to the apical membranes of distal-collecting duct cells [115]. Mice injected with epsilon-toxin-GFP exhibit severe kidney damage, including selective degeneration of distal nephrons. Epsilon-toxin also crosses the blood-brain-barrier, causing perivascular edema and neuronal damage that leads to release of glutamate responsible for neurological disorders characterized by convulsions and uncoordinated movements [116]. Because of the extreme potency and possible activity in humans, the National Institutes of Health and the Centers of Disease Control have classified epsilon-toxin as a Catergory B agent [117].

Epsilon-toxin is encoded by a gene located on a large plasmid [118], and the protein secreted as a non-active protoxin like many other clostridial toxins (Fig. 2, step 1). After secretion, proteolytic activation occurs by serine-type proteases like trypsin, $\alpha$-chymothrypsin, or the $C$. perfringens lambda protease in the gut of infected animals or in vitro (Fig. 2, step 2). Cleavage of $29 \mathrm{C}$-terminal residues from epsilon-toxin is essential for the biological activity and formation of large SDS-resistant heptameric complexes in rat synaptosomal membranes and target cell membranes $[119,120]$ (Table 1). The removal of $13 \mathrm{~N}$-terminal amino acids from epsilon-toxin is of secondary interest and induces only minor activation of toxin [48] (Table 1).

The structure of $C$. perfringens epsilon-toxin is highly related to that of aerolysin, despite low sequence identity (13.9 \%) (Fig 1B). Despite high structural similarity, epsilon-toxin shows a remarkable difference in its biological potency being 100 times more lethal in mice versus aerolysin and septicum-alpha-toxin [5, 49, 50]. A cluster of aromatic residues within domain 1 of epsilon-toxin might be related to receptor binding [5]. Epsilon-toxin binds to detergent resistant microdomains (DRMs), which leads to the possibility that a putative receptor is located in DRMs (Fig. 2, step 3 and 4). Phosphatidylinositol-specific phospholipase $\mathrm{C}$ (PI-PLC) does not impair binding or formation of epsilon-toxin complexes, suggesting that the receptor for epsilon-toxin is not GPI-anchored [121]. Furthermore, sphingolipid and cholesterol content influences susceptibility of host cells to epsilon-toxin and necessary heptamerization of the toxin [120, 122]. Addition of extracellular ganglioside $\mathrm{G}_{\mathrm{M} 1}$ causes a dramatic decrease in binding, heptamerization, and cytotoxicity [122]. Toxin binding induces oligomerization and formation of a heptameric complex in rat synaptosomal and Madin-Darby canine kidney (MDCK) cell membranes [119, 120, 123]. However, epsilon-toxin binds to a specific receptor on a restricted number of cell lines that include MDCK, human renal leiomyoblastoma G-402, and mouse renal mpkCCD (Table 1) [124], which is distinct from the GPI-anchored proteins recognized by aerolysin and septicum-alpha-toxin. It has been shown that epsilon-toxin binds to plasma membranes of MDCK cells, but not to any other intracellular organelles [123, 125]. Thus, epsilon-toxin heptamerizes and induces pore formation in target cell membranes, leading to a rapid change in membrane permeability and ultimately cell death $[120,123]$. Epsilon-toxin decreases intracellular $\mathrm{K}^{+}$, and increases $\mathrm{Cl}^{-}$as well as $\mathrm{Na}^{+}$, concentrations in MDCK cells[122] (Fig. 2, step 5). Furthermore, epsilon-toxin influences the cell cycle [126] and induces rapid cell death without altering tight junction permeability, the actin cytoskeleton network, or endocytotic processes [125]. It has also been possible to observe oligomerization and channel formation of epsilon-toxin in vitro using the black lipid bilayer technique [127]. Epsilon-toxin forms slightly anionselective channels in artificial membranes with a singlechannel conductance of $60 \mathrm{pS}$ in $100 \mathrm{mM} \mathrm{KCl}$ (Table 1). The channels are permeable to hydrophilic solutes with a molecular mass of at least $1 \mathrm{kDa}$, which probably represents the basic mechanism of toxin action upon target cells [127].

Epsilon-toxin induces rapid depletion of ATP, stimulates the AMP-activated protein kinase (AMPK), and influences cell signal pathways via mitochondrial membrane permeabilization and mitochondrial-nuclear translocation of apoptosis-inducing factor (AIF) (Fig. 2, step 5). Different than aerolysin [22, 83], epsilon-toxin induces cell necrosis instead of apoptosis [121] (Table 1). A characteristic trait of necrosis involves nuclear shrinkage without DNA fragmentation. Treatment of cells with a lipid raft disrupting agent, methyl- $\beta$-cyclodextrin (M $\beta C D)$, diminishes epsilontoxin oligomerization and distinctly reduces $\mathrm{Na}^{+}$and $\mathrm{Ca}^{2+}$ influx; however, ATP depletion and cell death is not prevented [121] (Fig. 2, step 5). The exact mechanism of epsilon-toxin induced cell death remains undetermined. Despite structural similarity with aerolysin, epsilon-toxin recognizes a distinct receptor on DRMs of target cells and is much more cytotoxic by inducing cell necrosis.

4. Toxins from Bacillus: Mtx from Bacillus sphaericus and Parasporin-2 from Bacillus thuringiensis (Gram-Positive, Prokaryotes)

The aerobic, spore-forming Bacillus sphaericus produces several insecticidal toxins. More than 380 different strains have been identified which are toxic to the larvae of Culex, Aedes, and Anopheles mosquitoes [128, 129]. The strains can be divided into low-and high-toxin producers [128, 130]. Both low and high toxicity strains produce a $100 \mathrm{kDa}$ toxin, whereas highly-toxic strains produce during sporulation an additional binary toxin consisting of 51.4 and $41.9 \mathrm{kDa}$ proteins [128, 131]. In addition to these toxins, Mtxs (Mtx1, Mtx2, Mtx3) have a different mode of action [132] and are produced during vegetative growth by both high- and low- 
toxicity strains $[131,133,134]$. Significant homologies have been found between the $31.8 \mathrm{kDa}$ Mtx2 [134], $35.8 \mathrm{kDa}$ Mtx3 (Table 1), epsilon-toxin [118], and Pseudomonas aeruginosa cytotoxin [134]. Mtx3 shares $38 \%$ identity with Mtx2, $30 \%$ with epsilon-toxin, and $27 \%$ with the $P$. aeruginosa cytotoxin [135]. The N-terminus contains a signal peptide (26 amino acids) $[133,136]$. In contrast to wild type Mtx3, recombinant toxin produced in E. coli is moderately toxic to Culex quinquefasciatus larvae and weakly toxic to Aedes aegypti larvae [133] (Table 1). Nothing is known about the toxic effects on cultured cells. It can be assumed that the receptor(s) for Mtx2 and Mtx3 is highly specific and restricted to gut cells of mosquito larvae. Mtx 2 shows $31 \%$ identity to the epsilon-toxin and $28 \%$ with the $P$. aeruginosa cytotoxin. Both Mtx2 and Mtx3 are widespread within high- and low-toxicity strains [133, 134]. Because of relatively dampened expression for Mtx2, and its degradation by the subtilisin-like serine proteinase sphericase [137, 138], its contribution to the toxicity of spores used for mosquito control is low [139]. However, Mtx2 is toxic to $C$. quinquefasciatus [134] and possesses significant activity against $A$. aegypti larvae [132].

Little is known about the toxic mechanism of the Mtxs and it still remains unknown if Mtx2 and Mtx3 are, like the other members of the aerolysin-like toxin family, secreted as protoxins requiring proteolytic activation [128, 129]. Because of relatively high sequence homologies with the epsilon-toxin and $P$. aeruginosa cytotoxin, it is thought that Mtx may also form pores on suitable target cells [133].

During sporulation, the Gram-positive, spore-forming Bacillus thuringiensis produces protein crystals also referred to as parasporal inclusions. These crystal proteins vary in size and composition among bacterial strains, and often exhibit insecticidal activity without any harmful effects on mammals [7]. The structure for one of these parasporal inclusion crystals, parasporin-2, has recently been solved. Four parasporins (parasporin-1 through parasporin-4) have been identified and characterized to date [140-143]. The structure of parasporin-2 is unique for the two currently classified, major crystal protein families: Cry and Cyt proteins [144-150]. Despite differences, parasporins are classified as Cry proteins in the $B$. thuringiensis toxin nomenclature. Interestingly, parasporin-2 cannot be assigned to one of the two groups of crystal proteins produced by $B$. thuringiensis, and displays striking similarities to the aerolysin-like toxin family (Fig. 3) (Table 1) [7]. Although parasporin-2 and these other protein toxins share a characteristic strand-dominated structure, there is only marginal sequence similarity $(25.7-27.7 \%$ identity between parasporin-2 and aerolysin, epsilon-toxin, or LSL). In addition, parasporin-2 shares $41 \%$ sequence identity with hydralysin from Chlorohydra viridissima [151] (see below). Therefore, it can be assumed that both proteins also share a common structure [7]. Like the epsilon-toxin and LSL, parasporin-2 consists of a single large loop composed of three domains. Domain 2 contains a putative channelforming $\beta$-hairpin. The surface has exposed side chains of serine and threonine residues possibly important during cell binding, oligomerization, and channel formation [7].

Parasporin-2 is produced as an inactive $37-\mathrm{kDa}$ protoxin requiring proteolytic nicking. Proteinase $\mathrm{K}$ removes 51 residues from its $\mathrm{N}$-terminus and 36 residues from the $\mathrm{C}$ terminus, resulting in a $30-\mathrm{kDa}$ active toxin that forms pores and increases plasma membrane permeability (Table 1) [7, $140,152]$. Exposure of cells to the toxin causes further swelling, blebbing, lysis, disassembly of the microtubule network, and fragmentation of mitochondria as well as ER [152]. The receptor for parasporin-2 is not yet known, but the toxin targets lipid rafts, undergoes dimerization, as well as inserts into lipid bilayers and membranes of sensitive cells [153]. Based upon structure homology with the aerolysinlike toxin family, parasporin-2 retains a conserved $\beta$-hairpin that forms a pore according to the rivet model, in which a single residue (Phe) between the two amphipathic $\beta$-strands contributes to a $\beta$-barrel anchor into the lipid bilayer [7].

Aside from the structure, parasporin-2 also has divers activities upon different cell types. While Cry proteins are toxic for specific insect species and Cyt proteins have broad cytolytic/hemolytic activity against invertebrate and vertebrate cells, parasporin-2 is particularly cytocidal to human liver and colon cancer cells. The $50 \%$ lethal dose for hepatic and colon cancer cell lines, as well as human leukemia T-cell lines, is around $20 \mathrm{ng} / \mathrm{ml}$ [152]. Parasporin-2 is neither insecticidal nor haemolytic $[154,155]$.

\section{Hemolytic Lectins from Laetiporus Sulphureus (LSL) (Eukaryote, Mushroom)}

Sugar binding proteins or glycoproteins of non-immune origins which agglutinate cells and precipitate glycoconjugates are called lectins [156]. The lectin produced by the parasitic and saprophytic mushroom L. sulphurous, possesses strong hemagglutination and haemolytic activity [52] (Table 1). This lectin-producing organism is widely distributed and grows namely during summer and fall in large clusters upon the decaying $\operatorname{logs}$ and stumps of hardwoods as well as conifers [157]. Closely related Laetiporus species ( $L$. cincinnatus, L. gilbertsonii, $L$. conifericola) exist [158] and perhaps share the same haemolytic lectins. The LSL lectin was first isolated by Konska et al. [159] and reported as a homotetramer with subunits of $\sim 35 \mathrm{KDa}$ [52] (Table 1).

Three similar full-length cDNAs, designated as LSLa, LSLb, and LSLc, have been detected through the analysis of a cDNA library derived from $L$. sulphureus. Each cDNA subtype has an open reading frame of $945 \mathrm{bp}$ encoding for 315 amino acids. Sequence homology between the three proteins is 80 to $90 \%$ [52]. LSLs share sequence homologies of about 22-25\% with the mosquitocidal toxin (MTX2) from B. sphaericus and septicum-alpha-toxin. The sugar binding $\mathrm{N}$-terminal part has a $\beta$-trefoil framework structurally similar to other toxins that interact with galactose-related carbohydrates, such as the hemagglutinin component (HA1) of the progenitor toxin from C. botulinum neurotoxin [6, 160]. The C-terminal portion consisting of domains 2 and 3 possesses structural similarity to domains 3 and 4 of aerolysin, as well as domains 2 and 3 of epsilon-toxin [160]. Like these toxins, LSL contains an amphipathic $\beta$-hairpin of about 30 amino acids. Furthermore, the crystal structure of LSL reveals a hexamer that contradicts the above-mentioned results indicating that LSL exists as a tetramer $[6,52]$.

All three lectin subtypes of LSL, as well as their recombinant forms, agglutinate and lyse rabbit, human and 
sheep erythrocytes via a colloid-osmotic mechanism [52]. The latter is characterized by compounds, such as sucrose or polyethylene glycol, that delay erythrocyte lysis by temporarily stabilizing osmotic pressure and preventing cell swelling caused by toxin-induced pores [161]. Haemolysis seemingly occurs through pore formation, and results of osmotic protection experiments show that haemolysis involves ion-permeable channels smaller than $3.8 \mathrm{~nm}$ diameter [52] (Table 1). Incubation of LSL with lacto-Nneotetraose and related saccharides inhibits cell binding and formation of trans-membrane pores, indicating that the lectin receptor contains $\mathrm{N}$-acetyllactosamine glycoconjugates. LSL contains in its $\mathrm{N}$-terminal region three tandemly repeated subdomains resembling segments of the ricin B-chain. The $\mathrm{N}$-terminus recognizes carbohydrates, since mutants with a C-terminal deletion retain cell agglutination function but lose haemolytic activity. The C-terminal region is also involved in oligomerization and pore formation [160].

\section{Hydralysins from Cnidaria (Eukaryote, Aquatic Animals)}

Recently, a new group of toxins designated as the hydralysins has been described in the literature [162, 163]. These toxins are produced by the cnidaria Chlorohydra viridis (Table 1), are distinct from other cnidarian toxins, and show similarities in activity and structure to toxins of the aerolysin-like toxin family. A functional characterization of hydralysins performed by Sher et al. [162] reveals that hydralysins are secreted as soluble monomers rich in $\beta$ structure [162]. Furthermore, it was shown that hydralysins bind to erythrocyte membranes via an unknown receptor(s), form discrete pores of $\sim 1.2 \mathrm{~nm}$ diameter (Table 1), and are cytolytic upon select cell types. Comparison of aerolysin, epsilon-toxin, alpha-toxin, and LSL sequences with hydralysin reveals conserved sequences, especially around the pore-forming domains. Since hydralysins are secreted onto captured prey by cells of the digestive system, it seems that such proteins are not involved in capturing prey. Instead, the function of hydralysins probably aids digestion of prey tissue. Therefore, hydralysins bind only to membranes of captured animals but evidently not to cells of Chlorohydra [163].

\section{MEMBERS OF THE AEROLYSIN FAMILY SHARE A CHANNEL MOTIF WITH THE BINARY TOXINS OF GRAM-POSITIVE BACTERIA}

Members of the aerolysin-like toxin family, and PFTs in general, are membrane-damaging toxins. They are generally active on the cell surface, causing pore formation and disruption of plasma membrane that subsequently leads to leakage and death of target cells. Although not described in this review, related $\beta$-PFTs include multi-component staphylococcal leukocidins and the oxygen-labile streptolysin O of Streptococcus pyogenes. These toxins form pores on cell membranes, but in addition streptolysin $\mathrm{O}$ mediates translocation of a NAD glycohydrolase into the cytosol of a target cell [164]. The channel-forming domains of leukocidins and streptolysin $\mathrm{O}$ share sequence homology with aerolysin-like toxin family members, especially epsilon-toxin. Similar B-PFT structures and mechanisms are also used by certain intracellularly-active binary toxins to cross the lipid bilayer.
Binary toxins are structurally organized into two distinct proteins not linked in solution and corresponding to enzymatic (A) plus binding (B) components. The binding component is responsible for receptor recognition and docking/transportation of the enzymatic component across endosomal membranes. Similar to $\beta$-PFTs, binding components such as PA from the lethal/edema toxins of $B$. anthracis, Ib of $C$. perfringens iota toxin, and $\mathrm{C} 2-\mathrm{II}$ from C2-toxin of $C$. botulinum are organized into four domains essentially composed of hydrophilic $\beta$-strands. The $\mathrm{N}$ terminal domain (domain 1) contains a propeptide and docking site for the enzymatic component, whereas the $\mathrm{C}$ terminal domain (domain 4) is responsible for cell-surface receptor interactions $[165,166]$. The smallest domain (domain 3) likely promotes oligomerization, and domain 2 contains long $\beta$-strands with an amphipathic flexible loop forming a $\beta$-hairpin intimately involved in pore formation [43, 167, 168]. Alignment of the putative channel-forming domain of epsilon-toxin with amphipathic beta hairpins of the binding components from binary iota- and C2-toxins show high sequence identity (Ib: 38\%, C2-II: 22\%) [169, 170]. In contrast to the aerolysin-like toxins and other cell membrane damaging toxins, the Clostridium and Bacillus binding components of binary toxins form pores at an acidic $\mathrm{pH}$ in endocytic vesicles and selectively transport enzymatic component into the cytosol [1]. Overall though, such data suggest that PFTs of the aerolysin-like and binary toxin families share common mechanisms of pore formation and a protein ancestor. As with many protein toxins, when closely scrutinized by various techniques and by different laboratories around the world, there are remarkable commonalities in structure and modes of actions. Perhaps more remarkable is how such proteins, which are true evolutionary successes, have become conserved amongst very diverse types of organisms and plants.

\section{ACKNOWLEDGEMENTS}

We would like to thank Kelly-Anne Baglot for critical reading of the manuscript. This work was financially supported by the Deutsche Forschungsgemeinschaft (KN 766/1-1) and Institut Pasteur, Paris.

\begin{tabular}{|c|c|c|}
\hline \multicolumn{3}{|c|}{ ABBREVIATIONS } \\
\hline PFT & $=$ & Pore-forming toxin \\
\hline PA & $=$ & Protective antigen \\
\hline LSL & $=$ & Laetiporus sulphureus lectin \\
\hline Mtxs & $=$ & Mosquitocidal toxins \\
\hline$(\mathrm{CD})-$ & $=$ & $\begin{array}{l}\text { Circular Dichroism spectroscopy } \\
\text { spectroscopy }\end{array}$ \\
\hline RTX-toxins & $=$ & Repeats in ToXin-toxins \\
\hline IP3 & $=$ & Inositol(1,4,5)-triphosphate \\
\hline MAPK & $=$ & Mitogen-activated protein kinase \\
\hline hFR & $=$ & Human folate receptor \\
\hline SAG-family & $=$ & Sensitive to apoptosis gene family \\
\hline GFP & $=$ & Green-Fluorescence Protein \\
\hline DRMs & $=$ & Detergent resistant microdomains \\
\hline MDCK cells & $=$ & Madin-Darby canine kidney cells \\
\hline
\end{tabular}




$$
\begin{array}{ll}
\text { GPI } & =\text { Glycosyl-phosphatidylinositol } \\
\text { LD }_{50} & =\text { Mouse median lethal dose }
\end{array}
$$

\section{REFERENCES}

[1] Geny B, Popoff MR. Bacterial protein toxins and lipids: pore formation or toxin entry into cells. Biol Cell 2006; 98: 667-78.

[2] Ballard J, Crabtree J, Roe BA, Tweten RK. The primary structure of Clostridium septicum alpha-toxin exhibits similarity with that of Aeromonas hydrophila aerolysin. Infect Immun 1995; 63: 340-4.

[3] Sousa MV, Richardson M, Fontes W, Morhy L. Homology between the seed cytolysin enterolobin and bacterial aerolysins. J Protein Chem 1994; 13: 659-67.

[4] Fontes W, Sousa MV, Aragão JB, Morhy L. Determination of the amino acid sequence of the plant cytolysin enterolobin. Arch Biochem Biophys 1997; 347: 201-7.

[5] Cole AR, Gibert M, Popoff MR, Moss DS, Titball RW, Basak AK. Clostridium perfringens epsilon-toxin shows structural similarity to the pore-forming toxin aerolysin. Nat Struct Mol Biol 2004; 11: 797-8.

[6] Mancheño JM, Tateno H, Goldstein IJ, Martínez-Ripoll M, Hermoso JA. Structural analysis of the Laetiporus sulphureus hemolytic pore-forming lectin in complex with sugars. J Biol Chem 2005; 280: 17251-9.

[7] Akiba T, Abe Y, Kitada S, et al. Crystal structure of the parasporin2 Bacillus thuringiensis toxin that recognizes cancer cells. J Mol Biol 2009; 386: 121-33.

[8] Tweten RK, Parker MW, Johnson AE. The cholesterol-dependent cytolysins. Curr Top Microbiol Immunol 2001; 257: 15-33.

[9] Melton JA, Tweten JM. In: Alouf JE, Popoff MR, Eds. The comprehensive sourcebook of bacterial protein toxins. $3^{\text {rd }}$ ed. London: Academic Press 2006; pp. 623-30.

[10] Parker MW, Buckley JT, Postma JP, et al. Structure of the Aeromonas toxin proaerolysin in its water-soluble and membranechannel states. Nature 1994; 367: 292-5.

[11] Iacovache I, Paumard P, Scheib H, et al. A rivet model for channel formation by aerolysin-like pore-forming toxins. EMBO J 2006; 25: 457-66.

[12] Bernheimer AW, Avigad LS, Avigad G. Interactions between aerolysin, erythrocytes, and erythrocyte membranes. Infect Immun 1975; 11: 1312-9.

[13] Austin B, Adams C. In: Austin B, Altweg M, Gosling PJ, Joseph SW, Eds. The genus Aeromonas. Chichester, UK: Wiley 1996; pp. 197-244.

[14] Howard SP, Buckley JT. Molecular cloning and expression in Escherichia coli of the structural gene for the hemolytic toxin aerolysin from Aeromonas hydrophila. Mol Gen Genet 1986; 204: 289-95.

[15] Howard SP, Garland WJ, Green MJ, Buckley JT. Nucleotide sequence of the gene for the hole-forming toxin aerolysin of Aeromonas hydrophila. J Bacteriol 1987; 169: 2869-71

[16] Chopra AK, Houston CW, Peterson JW, Jin GF. Cloning, Expression, and sequence analysis of a cytolytic enterotoxin gene from Aeromonas hydrophila. Can J Microbiol 1993; 39: 513-23.

[17] Wang G, Tyler KD, Munro CK, Johnson WM. Characterization of cytotoxic, hemolytic Aeromonas caviae clinical isolates and their identification by determining presence of a unique hemolysin gene. J Clin Micrbiol 1996; 34: 3203-5.

[18] Khan AA, Kim E, Cerniglia CE. Molecular cloning, nucleotide sequence, and expression in Escherichia coli of a hemolytic toxin (aerolysin) gene from Aeromonas trota. Appl Environ Microbiol 1998; 64: 2473-8.

[19] Kirov SM. In: Doyle M, Beuchat LR, Montville TJ, Eds. Food microbiology: fundamentals and frontiers. Washington DC: American Society for Microbiology 1997; pp. 265-87.

[20] Janda JM, Abbott SL. Evolving concepts regarding the genus Aeromonas: an expanding Panorama of species, disease presentations, and unanswered questions. Clin Infect Dis 1998; 27: 332-44.

[21] Thayumanavan T, Vivekanandhan G, Savithamani K, Subashkumar R, Lakshmanaperumalsamy P. Incidence of haemolysin-positive and drug-resistant Aeromonas hydrophila in freshly caught finfish and prawn collected from major commercial fishes of coastal South India. FEMS Immunol Med Microbiol 2003; 36: 41-5.
[22] Chopra AK, Xu X, Ribardo D, et al. The cytotoxic enterotoxin of Aeromonas hydrophila induces proinflammatory cytokine production and activates arachidonic acid metabolism in macrophages. Infect Immun 2000; 68: 2808-18.

[23] Chakraborty T, Huhle B, Hof H, Bergbauer H, Goebel W. Marker exchange mutagenesis of the aerolysin determinant in Aeromonas hydrophila demonstrates the role of aerolysin in A. hydrophilaassociated systemic infections. Infect Immun 1997; 55: 2274-80.

[24] Fivaz M, Abrami L, Tsitrin Y, van der Goot FG. Aerolysin from Aeromonas hydrophila and related toxins. Curr Top Microbiol Immunol 2001; 257: 35-52.

[25] Gurcel L, Iaocovache I, van der Goot FG. In: Alouf JE, Popoff MR, Eds. The comprehensive sourcebook of bacterial protein toxins. $3^{\text {rd }}$ ed. London: Academic Press 2006; pp. 623-30.

[26] Howard SP, Critch J, Bedi A. Isolation and analysis of eight exe genes and their involvement in extracellular protein secretion and out membrane assembly in Aeromonas hydrophila. J Bacteriol 1993; 175: 6695-703.

[27] Jahagirdar R, Howard SP. Isolation and characterization of a second exe operon required for extracellular protein secretion in Aeromonas hydrophila. J Bacteriol 1994; 176: 6819-26.

[28] Dalbey RE, Robinson C. Protein translocation into and across the bacterial plasma membrane and the plant thylakoid membrane. Trends Biochem Sci 1999; 24: 17-22.

[29] Hardie KR, Schulze A, Parker MW, Buckley JT. Vibrio spp. secrete proaerolysin as a folded dimer without the need for disulphide bond formation. Mol Microbiol 1995; 17: 1035-44.

[30] Howard SP, Meiklejohn HG, Shivak D, Jahagirdar R. A TonB-like protein and a novel membrane protein containing an ATP-binding cassette function together in exotoxin secretion. Mol Microbiol 1996; 22: 595-604.

[31] Ast VM, Schoenhofen IC, Langen GR, et al. Expression of the ExeAB complex of Aeromonas hydrophila is required for the localization and assembly of the ExeD secretion port multimer. Mol Microbiol 2002; 44: 217-31.

[32] Diep DB, Lawrence TS, Ausio J, Howard SP, Buckley JT. Secretion and properties of the large and small lobes of the channel-forming toxin aerolysin. Mol Microbiol 1998; 30: 341-52.

[33] Fivaz M, Velluz MC, van der Goot FG. Dimer dissociation of the pore-forming toxin aerolysin precedes receptor binding. J Biol Chem 1999; 274: 37705-8.

[34] van der Goot FG, Pattus F, Wong KR, Buckley JT. Oligomerization of the channel-forming toxin aerolysin precedes insertion into lipid bilayers. Biochemistry 1993; 32: 2636-42.

[35] Barry R, Moore S, Alonso A, Ausio J, Buckley JT. The channelforming protein proaerolysin remains a dimer at low concentrations in solution. J Biol Chem 2001; 276: 551-4.

[36] van der Goot FG, Lakey J, Pattus F, et al. Spectroscopic study of the activation and oligomerization of the channel-forming toxin aerolysin: identification of the site of proteolytic activation. Biochemistry 1992; 31: 8566-70.

[37] Rossjohn J, Raja SM, Nelson KL, et al. Movement of a loop in domain 3 of aerolysin is required for channel formation. Biochemistry 1998; 37: 741-6.

[38] Rossjohn J, Buckley JT, Hazes B, et al. Aerolysin and pertussis toxin share a common receptor-binding domain. EMBO J 1997; 16: 3426-34.

[39] MacKenzie CR, Hirama T, Buckley JT. Analysis of receptor binding by the channel-forming toxin aerolysin using surface plasmon resonance. J Biol Chem 1999; 274: 22604-9.

[40] Diep DB, Nelson KL, Lawrence TS, et al. Expression and properties of an aerolysin - Clostridium septicum alpha toxin hybrid protein. Mol Microbiol 1999; 31: 785-94.

[41] Lesieur C, Frutiger S, Hughes G, et al. Increased stability upon heptamerization of the pore-forming toxin aerolysin. J Biol Chem 1999; 274: 36722-8.

[42] Song L, Hobaugh MR, Shustak C, et al. Structure of staphylococcal alpha-hemolysin, a heptameric transmembrane pore. Science 1996; 274: 1859-66.

[43] Petosa C, Collier RJ, Klimpel KR, Leppla SH, Liddington RC. Crystal structure of the anthrax toxin protective antigen. Nature 1997; 385: 833-8.

[44] Benz R, Schmid A, Nakae T, Vos-Scheperkeuter GH. Pore formation by LamB of Escherichia coli in lipid bilayer membranes. J Bacteriol 1986; 165: 978-86. 
[45] Wilmsen HU, Leonhard KR, Tichelaar W, Buckly JT, Pattus F. The aerolysin membrane channel is formed by heptamerization of the monomer. EMBO J 1992; 11: 2457-63.

[46] Cabiaux V, Buckley JT, Wattiez R, et al. Conformational changes in aerolysin during the transition from the water-soluble protoxin to the membrane channel. Biochemistry 1997; 36; 15224-32.

[47] Nomura T, Fujii Y, Okamoto K. Secretion of hemolysin of Aeromonas sobria as protoxin and contribution of the propeptide region removed from the protoxin to the proteolytic stability of the toxin. Microbiol Immunol 1999; 43: 29-38

[48] Tsitrin Y, Morton CJ, el-Bez C, et al. Conversion of a transmembrane to a water-soluble protein complex by a single point mutation. Nat Struct Biol 2002; 9: 729-33.

[49] Minami J, Katayama S, Matsushita O, Matsushita C, Okabe A. Lambda-toxin of Clostridium perfringens activates the precursor of epsilon-toxin by releasing its $\mathrm{N}$ - and C-terminal peptides. Microbiol Immunol 1997; 41: 527-35.

[50] RK Tweten. Clostridium perfringens beta toxin and Clostridium septicum alpha toxin: their mechanisms and possible role in pathogenesis. Vet Microbiol 2001; 82: 1-9.

[51] Habeeb AF, Lee CL, Atassi MZ. Conformational studies on modified proteins and peptides. VII. Conformation of epsilonprototoxin and epsilon-toxin from Clostridium perfringens. Conformational changes associated with toxicity. Biochim Biophys Acta $1973 ; 322: 245-50$

[52] Tateno H, Goldstein IJ. Molecular cloning, expression, and characterization of novel hemolytic lectins from the mushroom Laetiporus sulphureus, which show homology to bacterial toxins. J Biol Chem 2003; 278: 40455-63.

[53] Melton-Witt JA, Bentsen LM, Tweten RK. Identification of functional domains of Clostridium septicum alpha toxin. Biochemistry 2006; 45: 14347-54

[54] Cowell S, Aschauer W, Gruber HJ, Nelson KL, Buckley JT. The erythrocyte receptor for the channel-forming toxin aerolysin is a novel glycosylphosphatidylinositol-anchored protein. Mol Microbiol 1997; 25: 343-50.

[55] Nelson KL, Raja SM, Buckley JT. The glycosylphosphatidylinositol-anchored surface glycoprotein Thy-1 is a receptor for the channel-forming toxin aerolysin. J Biol Chem 1997; 272: 12170-4

[56] Abrami L, Fivaz M, Glauser PE, Parton RG, van der Goot FG. A pore-forming toxin interacts with a GPI-anchored protein and causes vacuolation of the endoplasmic reticulum. J Cell Biol 1998; 140: $525-40$

[57] Gurcel L, Abrami L, Girardin S, Tschopp J, van der Goot FG. Caspase-1 activation of lipid metabolic pathways in response to bacterial pore-forming toxins promotes cell survival. Cell 2006; 126: $1135-45$

[58] Pearson TW, Saya LE, Howard SP, Buckley JT. The use of aerolysin toxin as an aid for visualization of low numbers of African trypanosomes in whole blood. Acta Trop 1982; 39: 73-77.

[59] Ferguson MAJ. The structure, biosynthesis and functions of glycosyl-phosphatidylinositol anchors, and the contributions of trypanosome research. J Cell Sci 1999; 112: 2799-809.

[60] Zheng Z, Tweten RK, Mensa-Wilmot K. Intracellular glycosylphosphatidyl-inositols accumulate on endosomes: toxicity of alpha-toxin to Leishmania major. Eukaryot Cell 2005; 4: 55666.

[61] Abrami L, Velluz MC, Hong Y, et al. The glycan core of GPIanchored proteins modulates aerolysin binding but is not sufficient: the polypeptide moiety is required for the toxin-receptor interaction. FEBS Lett 2002; 512: 249-54.

[62] Gordon VM, Nelson KL, Buckley JT, et al. Clostridium septicum alpha toxin uses glycosylphosphatidy-linositol-anchored protein receptors. J Biol Chem 1999; 274: 27274-80.

[63] Abrami L, Fivaz M, Decroly E, et al. The pore-forming toxin proaerolysin is activated by furin. J Biol Chem 1998; 273: 3265661.

[64] Garland WJ, Buckley JT. The cytolytic toxin aerolysin must aggregate to disrupt erythrocytes, and aggregation is stimulated by human glycophorin. Infect Immun 1988; 56: 1249-53.

[65] van der Goot FG, Hardie KR, Parker MW, Buckley JT. The Cterminal peptide produced upon proteolytic activation of the cytolytic toxin aerolysin is not involved in channel formation. $\mathbf{J}$ Biol Chem 1994; 269: 30496-501.
[66] Abrami L, van der Goot FG. Plasma membrane microdomains act as concentration platforms to facilitate intoxication by aerolysin. J Cell Biol 1999; 147: 175-84.

[67] Wilmsen HU, Buckley JT, Pattus F. Site-directed mutagenesis at histidines of aerolysin from Aeromonas hydrophila: a lipid planar bilayer study. Mol Microbiol 1991; 5: 2745-51.

[68] Green MJ, Buckley JT. Site-directed mutagenesis of the holeforming toxin aerolysin: studies on the roles of histidines in receptor binding and oligomerization of the monomer. Biochemistry 1990; 29: 2177-80.

[69] Buckley JT, Wilmsen HU, Lesieur C, et al. Protonation of His-132 promotes oligomerization of the channel-forming toxin Aerolysin. Biochemistry 1995; 43: 16450-5.

[70] Valeva A, Weisser A, Walker B, et al. Molecular architecture of toxin pore: a 15-residue sequence lines the transmembrane channel of staphylococcal alpha-toxin. EMBO J 1996; 15: 1857-64.

[71] Bayley H. Triggers and switches in a self-assembling pore-forming protein. J Cell Biochem 1994; 56: 177-82.

[72] Knapp O, Maier E, Masín J, Sebo P, Benz R. Pore formation by the Bordetella adenylate cyclase toxin in lipid bilayer membranes: role of voltage and pH. Biochim Biophys Acta 2008; 1778: 260-9.

[73] Ostolaza H, Bakás L, Goñi FM. Balance of electrostatic and hydrophobic interactions in the lysis of model membranes by $E$. coli alpha-haemolysin. J Membr Biol 1997; 158: 137-45.

[74] Bakás L, Ostolaza H, Vaz WL, Goñi FM. Reversible adsorption and nonreversible insertion of Escherichia coli alpha-hemolysin into lipid bilayers. Biophys J 1996; 71: 1869-76.

[75] Imagawa T, Dohi Y, Higashi Y. Cloning, nucleotide sequence and expression of a hemolysin gene of Clostridium septicum. FEMS Microbiol Lett 1994; 117: 287-92.

[76] Melton JA, Parker MW, Rossjohn J, Buckley JT, Tweten RK. The identification and structure of the membrane-spanning domain of the Clostridium septicum alpha toxin. J Biol Chem 2004; 279: 14315-22.

[77] Ballard J, Sokolov Y, Yuan WL, Kagan BL, Tweten RK. Activation and mechanism of Clostridium septicum alpha toxin Mol Microbiol 1993; 10: 627-34.

[78] Chakraborty T, Schmid A, Notermans S, Benz R. Aerolysin of Aeromonas sobria: Evidence for formation of ion-permeable channels and comparison with alpha-toxin of Staphylococcus aureus. Infect Immun 1990; 58: 2127-32.

[79] Gouaux E. Alpha-hemolysin from Staphylococcus aureus: an archetype of beta-barrel, channel-forming toxins. J Struct Biol 1998; 121: 110-22

[80] Howard SP, Buckley JT. Membrane glycoprotein receptor and hole-forming properties of a cytolytic protein toxin. Biochemistry 1982; 21: 1662-7.

[81] Tschödrich-Rotter M, Kubitscheck U, Ugochukwu G, Buckley JT, Peters R. Optical single-channel analysis of the aerolysin pore in erythrocyte membranes. Biophys J 1996; 70: 723-32.

[82] Krause KH, Fivaz M, Monod A, van der Goot FG. Aerolysin induces $\mathrm{G}$-protein activation and $\mathrm{Ca}^{2+}$ release from intracellular stores in human granulocytes. J Biol Chem 1998; 273: 18122-9.

[83] Dinarello CA. A signal for the caspase-1 inflammasome free of TLR. Immunity 2007; 26:383-5.

[84] Nelson KL, Brodsky RA, Buckley JT. Channels formed by subnanomolar concentrations of the toxin aerolysin trigger apoptosis of T lymphomas. Cell Microbiol 1999; 1: 69-74.

[85] Galindo CL, Sha J, Ribardo DA, et al. Identification of Aeromonas hydrophila cytotoxic enterotoxin-induced genes in macrophages using microarrays. J Biol Chem 2003; 278: 40198-212.

[86] Galindo CL, Fadl AA, Sha J, et al. Aeromonas hydrophila cytotoxic enterotoxin activates mitogen-activated protein kinase and induces apoptosis in murine macrophages and human intestinal epithelial cells. J Biol Chem 2004; 279: 37597-612.

[87] Huffman DL, Abrami L, Sasik R, et al. Mitogen-activated protein kinase pathways defend against bacterial pore-forming toxins. Proc Natl Acad Sci USA 2004; 101: 10995-1000.

[88] Husmann M, Dersch K, Bobkiewicz W, et al. Differential role of p38 mitogen activated protein kinase for cellular recovery from attack by pore-forming $S$. aureus alpha-toxin or streptolysin $\mathrm{O}$. Biochem Biophys Res Commun 2006; 344: 1128-34.

[89] Stevens DL, Musher DM, Watson DA, et al. Spontaneous, nontraumatic gangrene due to Clostridium septicum. Rev Infect Dis 1990 12: 286-96.

[90] Hatheway CL. Toxigenic clostridia. Clin Microbiol 1990; 3: 66-98. 
[91] Abella BS, Kuchinic P, Hiraoka T, Howes DS. Atraumatic clostridial myonecrosis: case report and literature review. J Emerg Med 2003; 24: 401-5.

[92] Kennedy CL, Krejany EO, Young LF, et al. The alpha-toxin of Clostridium septicum is essential for virulence. Mol Microbiol 2005; 57: 1357-66.

[93] Gordon VM, Benz R, Fujii K, Leppla SH, Tweten RK. Clostridium septicum alpha-toxin is proteolytically activated by furin. Infect Immun 1997; 65: 4130-4.

[94] Hangómbe MB, Mukamoto M, Kohda T, Sugimoto N, Kozaki S. Cytotoxicity of Clostridium septicum alpha-toxin: its oligomerization in detergent resistant membranes of mammalian cells. Microbiol Pathogenesis 2004; 37: 279-86.

[95] Wichroski MJ, Melton JA, Donahue CG, Tweten RK, Ward GE. Clostridium septicum alpha-toxin is active against the parasitic protozoan Toxoplasma gondii and targets members of the SAG family of glycosylphosphatidyl-inositol-anchored surface proteins. Infect Immun 2002; 70: 4353-61.

[96] Amimoto K, Sasaki Y, Fukuyama S, Tamura Y. Genetic variation and cross-reactivity of Clostridium septicum alpha-toxin. Vet Microbiol 2006; 114: 51-59.

[97] Ballard J, Bryant A, Stevens D, Tweten RK. Purification and characterization of the lethal toxin (alpha-toxin) of Clostridium septicum. Infect Immun 1992; 60: 784-90.

[98] Sellman BR, Tweten RK. The propeptide of Clostridium septicum alpha toxin functions as an intramolecular chaperone and is a potent inhibitor of alpha toxin-dependent cytolysis. Mol Microbiol 1997; 25: 429-40.

[99] Hong Y, Ohishi K, Inoue N, et al. Requirement of N-glycan on GPI-anchored proteins for efficient binding of aerolysin but not Clostridium septicum alpha-toxin. Embo J 2002; 21: 5047-56.

[100] Knapp O, Maier E, Ben Mkaddem S, et al. Clostridium septicum alpha-toxin forms pores and induces rapid cell necrosis. Toxicon 2009; 2010; 55: 61-72.

[101] Kennedy CL, Smith DJ, Lyras D, Chakravorty A, Rood JI. Programmed cellular necrosis mediated by the pore-forming alphatoxin from Clostridium septicum. PLoS Pathog 2009; 5: e1000516.

[102] de Sousa MV, Morhy L. Enterolobin, a hemolytic protein from Enterolobium contortisiliquum seeds (Leguminosae-Mimosoideae). Purification and character ization. An Acad Bras Cienc 1989; 61: 405-12.

[103] Bittencourt SE, Silva LP, Azevedo RB, et al. The plant cytolytic protein enterolobin assumes a dimeric structure in solution. FEBS Lett 2003; 549: 47-51.

[104] Castro-Faria-Neto HC, Cordeiro RS, Martins MA, et al. Enterolobin induces rat paw oedema independently of PAF-acether. Mem Inst Oswaldo Cruz 1991; 86: 129-31.

[105] Grecco FB, Dantas AF, Riet-Correa F, Leite CG, Raposo JB. Cattle intoxication from Enterolobium contortisiliquum pods. Vet Hum Toxicol 2002; 44: 160-2.

[106] Brooks ME, Sterne M, Warrack GH. A reassessment of the criteria used for type differentiation of Clostridia perfringens. J Pathol Bacteriol 1957; 75: 185-95.

[107] Petit L, Gibert M, Popoff MR. Clostridium perfringens: toxinotype and genotype. Trends Microbiol 1999; 7: 104-10.

[108] Payne D, Oyston P. In: Rood JI, McClane BA, Songer JG, Titball RW, Eds. The clostridia: molecular biology and pathogenisis: London: Academic Press 1997.

[109] Nagahama M, Ochi S, Sakurai J. Assembly of Clostridium perfringens epsilon-toxin on MDCK cell membrane. J Nat Toxins 1998; 7: 291-302.

[110] Nagahama M, Sakurai J. Distribution of labelled Clostridium perfringens epsilon toxin in mice. Toxicon 1991; 29: 211-7.

[111] Sakurai J, Nagahama M. Tryptophan content of Clostridium perfringens epsilon toxin. Infect Immun 1995; 47: 260-3.

[112] Uzal FA, Kelly WR, Morris WE, Assis RA. Effects of intravenous injection of Clostridium perfringens type D epsilon toxin in calves. J Comp Pathol 2002; 126: 71-5.

[113] Nagahama M, Sakura J. High-affinity binding of Clostridium perfringens epsilon-toxin to rat brain. Infect Immun 1992; 60: 1237-40.

[114] Sakurai J, Nagahama M, Fujii Y. Effect of Clostridium perfringens epsilon toxin on the cardiovascular system of rats. Infect Immun 1983; 42: 1183-6.
[115] Soler-Jover A, Blasi J, Gómez de Aranda I, et al. Effect of epsilon toxin-GFP on MDCK cells and renal tubules in vivo. J Histochem Cytochem 2004; 52: 931-42.

[116] Miyamoto O, Sumitani K, Nakamura T, et al. Clostridium perfringens epsilon toxin causes excessive release of glutamate in the mouse hippocampus. FEMS Microbiol Lett 2000; 189: 109-13.

[117] Mantis NJ. Vaccines against the category B toxins: staphylococcal enterotoxin B, epsilon toxin and ricin. Adv Drug Deliv Rev 2005; 57: 1424-39.

[118] Hunter SE, Clarke IN, Kelly DC, Titball RW. Cloning and nucleotide sequencing of the Clostridium perfringens epsilon-toxin gene and its expression in Escherichia coli. Infect Immun 1992: 60: 102-10.

[119] Miyata S, Matsushita O, Minami J, et al. Cleavage of a C-terminal peptide is essential for heptamerization of Clostridium perfringens epsilon-toxin in the synaptosomal membrane. J Biol Chem 2001; 276: 13778-83.

[120] Miyata S, Minami J, Tamai E, et al. Clostridium perfringens epsilon-toxin forms a heptameric pore within the detergentinsoluble microdomains of Madin-Darby canine kidney cells and rat synaptosomes. J Biol Chem 2002; 277: 39463-8.

[121] Chassin C, Bens M, de Barry J, et al. Pore-forming epsilon toxin causes membrane permeabilization and rapid ATP depletionmediated cell death in renal collecting duct cells. Am J Physiol Renal Physiol 2007; 293: 927-37.

[122] Shimamoto S, Tamai E, Matsushita O, et al. Changes in ganglioside content affect the binding of Clostridium perfringens epsilon-toxin to detergent-resistant membranes of Madin-Darby canine kidney cells. Microbiol Immunol 2005; 49: 245-53.

[123] Petit L, Gibert M, Gillet D, et al. Clostridium perfringens epsilontoxin acts on MDCK cells by forming a large membrane complex. J Bacteriol 1997; 179: 6480-7.

[124] Shortt SJ, Titball RW, Lindsay CD. An assessment of the in vitro toxicology of Clostridium perfringens type D epsilon-toxin in human and animal cells. Hum Exp Toxicol 2000; 19: 108-16.

[125] Petit L, Gibert M, Gourch A, et al. Clostridium perfringens epsilon-toxin rapidly decreases membrane barrier permeability of polarized MDCK cells. Cell Microbiol 2003; 5: 155-64.

[126] Borrmann E, Gunther H, Kohler H. Effect of Clostridium perfringens epsilon toxin on MDCK cells. FEMS Immunol Med Microbiol 2001; 31: 85-92.

[127] Petit L, Maier E, Gibert M, Popoff MR, Benz R. Clostridium perfringens epsilon toxin induces a rapid change of cell membrane permeability to ions and forms channels in artificial lipid bilayers. J Biol Chem 2001; 276: 15736-40.

[128] Baumann P, Clark MA, Baumann L, Broadwell AH. Bacillus sphaericus as a mosquito pathogen: properties of the organism and its toxins. Microbiol Rev 1991; 55: 425-36.

[129] de Barjac H, Véron M, Cosmao Dumanoir V. Biochemical and serological characterization of "Bacillus sphaericus" strains, pathogenic or non-pathogenic for mosquitoes (author's transl). Ann Microbiol 1980; 131: 191-201.

[130] Porter AG, Davidson EW, Lui JW. Mosquitocidal toxins of bacilli and their genetic manipulation for effective biological control of mosquitoes. Microbiol Rev 1993; 57: 838-61.

[131] Thanabalu T, Hindley J, Jackson-Yap J, Barry C. Cloning, sequencing, and expression of a gene encoding a 100-kilodalton mosquitocidal toxin from Bacillus spaerius SSII-1. J Bacteriol 1991; 173: 2776-85.

[132] Thanabalu T, Hindley J, Barry C. Proteolytic processing of the mosquitocidal toxin from Bacillus spaerius SSII-1. J Bacteriol 1992; 174: 5051-56.

[133] Liu JW, Porter AG, Wee BY, Thanabalu T. New gene from nine Bacillus sphaericus strains encoding highly conserved 35.8kilodalton mosquitocidal toxins. Appl Environ Microbiol 1996; 62: 2174-6.

[134] Thanabalu T, Porter AG. A Bacillus sphaericus gene encoding a novel type of mosquitocidal toxin of $31.8 \mathrm{kDa}$. Gene 1996; 170: 85-9.

[135] Hayashi T, Kamio Y, Hishinuma F, et al. Pseudomonas aeruginosa cytotoxin: the nucleotide sequence of the gene and the mechanism of activation of the protoxin. Mol Microbiol 1989; 3: 861-8.

[136] Chang S. Engineering for protein secretion in Gram-positive bacteria. Methods Enzymol 1987; 153; 507-16. 
[137] Almog O, González A, Klein D, et al. The 0.93A crystal structure of sphericase: a calcium-loaded serine protease from Bacillus sphaericus. J Mol Biol 2003; 332: 1071-82.

[138] Tati MR, Thanabalu T, Porter AG. Gene from tropical Bacillus sphaericus encoding a protease closely related to subtilisins from Antarctic bacilli. Biochim Biophys Acta 1997; 1352: 56-62.

[139] Zhang B, Liu M, Yang Y, Yuan Z. Cytolytic toxin Cyt1Aa of Bacillus thuringiensis synergizes the mosquitocidal toxin Mtx1 of Bacillus sphaericus. Biosci Biotechnol Biochem 2006; 70: 2199204.

[140] Ito A, Sasaguri Y, Kitada S, et al. A Bacillus thuringiensis crystal protein with selective cytocidal action to human cells. J Biol Chem 2004; 279: 21282-6.

[141] Katayama H, Yokota H, Akao T, et al. Parasporin-1, a novel cytotoxic protein to human cells from non-insecticidal parasporal inclusions of Bacillus thuringiensis. J Biochem 2005; 137: 17-25.

[142] Yamashita S, Akao T, Mizuki E, et al. Characterization of the anticancer-cell parasporal proteins of a Bacillus thuringiensis isolate. Can J Microbiol 2000; 46: 913-9.

[143] Lee DW, Akao T, Yamashita S, et al. Noninsecticidal parasporal proteins of a Bacillus thuringiensis serovar shandongiensis isolate exhibit a preferential cytotoxicity against human leukemic $\mathrm{T}$ cells. Biochem Biophys Res Commun 2000; 272: 218-23.

[144] Li JD, Carroll J, Ellar DJ. Crystal structure of insecticidal deltaendotoxin from Bacillus thuringiensis at 2.5 A resolution. Nature 1991; 353: 815-21.

[145] Grochulski P, Masson L, Borisova S, et al. Bacillus thuringiensis CryIA(a) insecticidal toxin: crystal structure and channel formation. J Mol Biol 1995; 254: 447-64.

[146] Li J, Koni PA, Ellar DJ. Structure of the mosquitocidal deltaendotoxin CytB from Bacillus thuringiensis sp. kyushuensis and implications for membrane pore formation. J Mol Biol 1996; 257: 129-52.

[147] Morse RJ, Yamamoto T, Stroud RM. Structure of Cry2Aa suggests an unexpected receptor binding epitope. Structure 2001; 9: 409-17.

[148] Galitsky N, Cody V, Wojtczak A, et al. Structure of the insecticidal bacterial delta-endotoxin Cry3Bb1 of Bacillus thuringiensis. Acta Crystallogr D Biol Crystallogr 2001; 57: 1101-9.

[149] Boonserm P, Davis P, Ellar DJ, Li J. Crystal structure of the mosquito-larvicidal toxin Cry4Ba and its biological implications. J Mol Biol 2005; 348: 363-82.

[150] Boonserm P, Mo M, Angsuthanasombat C, Lescar J. Structure of the functional form of the mosquito larvicidal Cry4Aa toxin from Bacillus thuringiensis at a 2.8-angstrom resolution. J Bacteriol 2006; 188: 3391-401.

[151] Zhan M, Fishman Y, Sher D, Zlotkin E. Hydralysin, a novel animal group-selective paralytic and cytolytic protein from a noncnidocystic origin in hydra. Biochemistry 2003; 42: 8939-44.

[152] Kitada S, Abe Y, Shimada $\mathrm{H}$, et al. Cytocidal actions of parasporin-2, an anti-tumor crystal toxin from Bacillus thuringiensis. J Biol Chem 2006; 281: 26350-60.

[153] Abe Y, Shimada H, Kitada S. Raft-targeting and oligomerization of parasporin-2, a Bacillus thuringiensis crystal protein with antitumour activity. J Biochem 2008; 143: 269-75.
[154] Mizuki E, Ohba M, Akao T, et al. Unique activity associated with non-insecticidal Bacillus thuringiensis parasporal inclusions: in vitro cell-killing action on human cancer cells. J Appl Microbiol 1999; 86: 477-86.

[155] Mizuki E, Park YS, Saitoh H, et al. Parasporin, a human leukemic cell-recognizing parasporal protein of Bacillus thuringiensis. Clin Diagn Lab Immunol 2000; 7: 625-34.

[156] Goldstein IJ, Hughes RC, Monsigny M, Osawa T, Sharon N. What should be called a lectin? Nature 1980; 285: 66

[157] Mushroomexpert. [homepage on the Internet]. Kua M. Laetiporus cincinnatus. [2005 March] Available from: http://www.mushroomexpert.com/laetiporuscincinnatus .html

[158] Burdsall Jr HH, Banik MT. The genus Laetiporus in North America. Harvard Papers Botany 2001; 6: 43-55

[159] Konska G, Guillot J, Dusser M, Damez M, Botton B. Isolation and characterization of an $\mathrm{N}$-acetyllactosamine-binding lectin from the mushroom Laetiporus sulfureus. J Biochem 1994; 116: 519-23.

[160] Mancheño JM, Tateno H, Goldstein IJ, Hermoso JA Crystallization and preliminary crystallographic analysis of a novel haemolytic lectin from the mushroom Laetiporus sulphureus, Acta Crystallogr. D Biol Crystallogr 2004; 60: 1139-41.

[161] Harris RW, Sims PJ, Tweten RK. Evidence that Clostridium perfringens theta-toxin induces colloid-osmotic lysis of erythrocytes. Infect Immun 1991; 59: 2499-501.

[162] Sher D, Fishman Y, Zhang M, et al.. Hydralysins, a new category of beta-pore-forming toxins in cnidaria. J Biol Chem 2005; 280: 22847-55.

[163] Sher D, Fishman Y, Melamed-Book N, Zhang M, Zlotkin E. Osmotically driven prey disintegration in the gastrovascular cavity of the green hydra by a pore-forming protein. FASEB J 2008; 22: 207-14.

[164] Ghosh J, Caparon MG. Specificity of Streptococcus pyogenes $\mathrm{NAD}(+)$ glyco-hydrolase in cytolysin-mediated translocation. Mol Microbiol 2006; 62: 1203-14.

[165] Blöcker D, Barth H, Maier E, Benz R, Barbieri JT, Aktories K. The C terminus of component C2II of Clostridium botulinum C2 toxin is essential for receptor binding. Infect Immun 2000; 68: 4566-73.

[166] Marvaud JC, Smith T, Hale ML, et al. Clostridium perfringens iota-toxin: mapping of receptor binding and Ia docking domains on Ib. Infect Immun 2001; 69: 2435-41.

[167] Cunningham K, Lacy DB, Mogridge J, Collier RJ. Mapping the lethal factor and edema factor binding sites on oligomeric anthrax protective antigen. Proc Natl Acad Sci USA 2002; 99: 7049-53.

[168] Mogridge J, Cunningham K, Lacy DB, Mourez M, Collier RJ. The lethal and edema factors of anthrax toxin bind only to oligomeric forms of the protective antigen. Proc Natl Acad Sci USA 2002; 99: 7045-8.

[169] Knapp O, Benz R, Gibert M, Marvaud JC, Popoff MR. Interaction of Clostridium perfringens iota-toxin with lipid bilayer membranes. Demonstration of channel formation by the activated binding component Ib and channel block by the enzyme component Ia. J Biol Chem 2002; 277: 6143-52.

[170] Leppla SH. In: Alouf JE, Popoff MR, Eds. The comprehensive sourcebook of bacterial protein toxins. $3^{\text {rd }}$ ed. London: Academic Press 2006; pp. 323-47. 